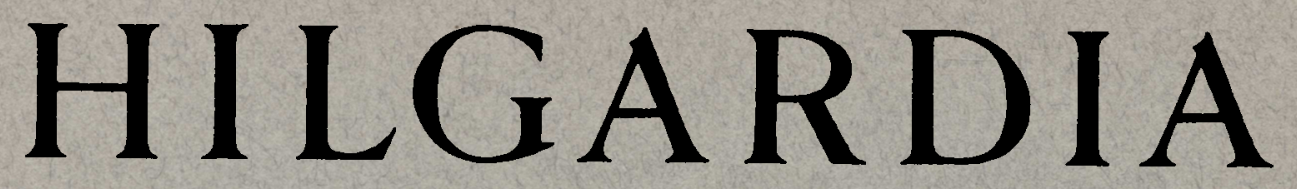

A Journal of Agricultural Science Published by the California Agricultural Experiment Station

\title{
APHIDS FEEDING ON CELERY IN CALIFORNIA
}

E. O. ESSIG

\section{WESTERN CELERY MOSAIC}

HENRY H. P. SEVERIN and JULIUS H. FREITAG 
WESTERN CELERY MOSAIC

HENRY H. P. SEVERIN AND JULIUS H. FREITAG 


\section{CONTENTS}

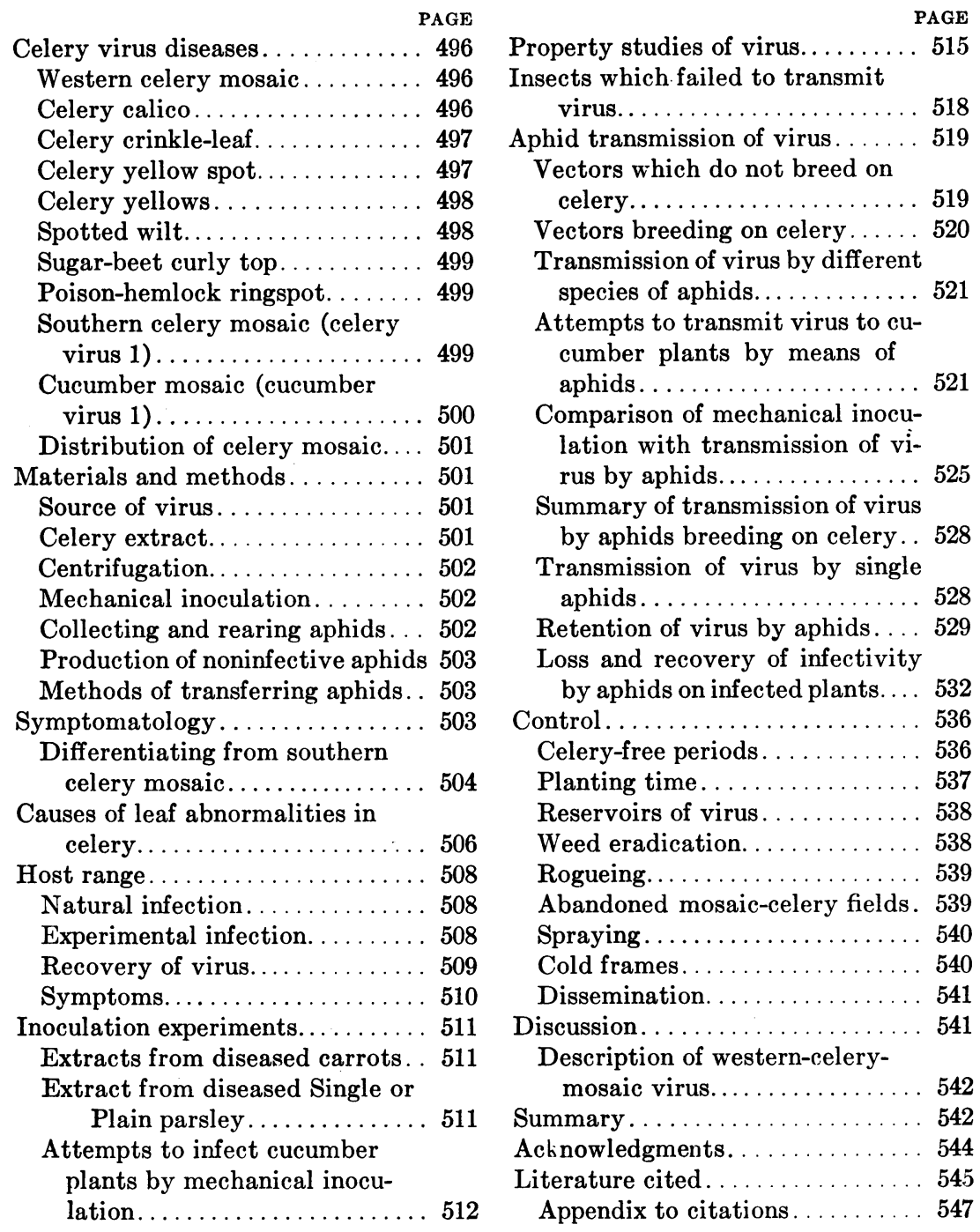




\section{WESTERN CELERY MOSAIC}

\section{HENRY H. P. SEVERIN ${ }^{2}$ AND JULIUS H. FREITAG ${ }^{3}$}

WESTERN CELERY MOSAIC has increased in the celery-growing districts in Los Angeles, Orange, San Mateo, Santa Clara, Alameda, Yolo, and Sacramento counties and is causing serious losses to the growers. The destructiveness of western celery mosaic was evidenced by a reduction in yield in the Venice district: Milbrath (17) ${ }^{4}$ reported that in 1932 a total of 2,737 cars of celery went from that district; in 1933 there were about 982 cars, and the estimate for 1934 is less than 500 from approximately the same acreage. Brock (1) estimated that in 1934 celery mosaic in the Venice district reduced the production of celery to about 16 per cent of normal car loadings. The decline in yields during 1930-1934 in two celery districts in Los Angeles County is shown in table 1.

\section{TABLE 1}

Yields of Celery in the Venice and Culver Districts, LOS ANGELES CoUnty

\begin{tabular}{|c|c|c|c|}
\hline Year & Acreage & $\begin{array}{l}\text { Yield per } \\
\text { acre, in half } \\
\text { crates }\end{array}$ & $\begin{array}{l}\text { Production, } \\
\text { in } \\
\text { half crates }\end{array}$ \\
\hline 1930. & 700 & 1,026 & 718,200 \\
\hline 1931. & 1,100 & 740 & 814,000 \\
\hline 1932. & 1,500 & 661 & 991,500 \\
\hline 1933. & 1,300 & 555 & 721,500 \\
\hline $1934 \ldots \ldots \ldots$ & 900 & 311 & 279,900 \\
\hline $1935^{*} \ldots \ldots \ldots$ & 200 & 800 & 160,000 \\
\hline $1936 \nmid \ldots \ldots \ldots$ & 950 & 926 & 879,700 \\
\hline $1937 \dagger \ldots \ldots \ldots \ldots \ldots \ldots \ldots \ldots$ & 950 & 847 & 804,650 \\
\hline
\end{tabular}

\footnotetext{
Sources of data:

* 1930-1931: from Milbrath $(18,19)$.

† 1932 1937: Milbrath, D. G., and Harold J. Ryan. A method of control of western celery mosaic. California State Dept. Agr. Mo. Bul. 27 (3): 290-95. 1938.
}

In 1933 the f.o.b. value of the celery crop in Los Angeles County was $\$ 1,965,455$. This value was exceeded by only two other crops-citrus and walnuts. In 1934 , the f.o.b. value of the celery crop was $\$ 838,490$; the celery crop was fifth in importance..$^{5}$

Celery infected with western celery mosaic when shipped to the middle western and eastern markets becomes soft in transit according to growers.

${ }^{1}$ Received for publication November 15, 1937.

${ }^{2}$ Associate Entomologist in the Experiment Station.

${ }^{3}$ Junior Entomologist in the Experiment Station.

"Italic figures in parentheses refer to "Literature Cited" at the end of this paper.

${ }^{5}$ Milbrath, D. G., letter to senior author dated September 16, 1935. 
This results in a total loss to the grower, who, in addition, is required to pay the freight. In the local markets diseased celery also becomes soft when kept on the vegetable stands for a few days.

An investigation was undertaken on the host range, properties of the virus, and the relative importance of different species of aphid vectors of the virus of western celery mosaic. Other aspects of aphid transmission of the virus of western celery mosaic discussed in this paper include a comparison of the transmission of the virus by different species of aphids with mechanical inoculation, a comparison of the transmission of the virus by single winged and wingless mature aphids, the retention of the virus by aphids, and loss and recovery of the infectivity by aphids on inoculated plants.

\section{CELERY VIRUS DISEASES}

Six virus diseases of celery (Apium graveolens var. dulce) occur under natural conditions in California as follows : western celery mosaic, celery calico, celery yellow spot, celery crinkle-leaf, celery yellows (the virus is identical with California aster yellows), and spotted wilt. Celery has been experimentally infected with the virus of poison-hemlock ringspot and sugar-beet curly top, but these diseases have not been found in celery fields up to the present time. Some of the virus diseases of celery discussed in the following paragraphs have been shown to be caused by the cucumber-mosaic virus or a strain of this virus. A brief review of the occurrence of celery-mosaic diseases in the United States and Europe is given.

Western Celery Mosaic.-Celery mosaic from California differs from southern celery mosaic in symptoms and host ranges (to be discussed later), and the viruses differ in properties. The common name "western celery mosaic" was therefore suggested (32) for the California disease to distinguish it from southern celery mosaic. The disease is common in the Fog Belt of California and also occurs in the hot interior regions, such as the Sacramento Valley.

Celery Calico.-The common name used by the present writers (32) for another celery mosaic disease is "calico." Considerable variation occurs in the development of the early symptoms of celery calico. The symptom which sometimes develops first in the greenhouse is a clearing of the veins with a slight yellowing along them (plate $1, A$ ), accompanied by a puckering and downward cupping of the younger leaves. Frequently no vein clearing occurs, but a faint yellowing develops near the basal region of the leaflets (plate $1, B$ ), or pale-yellow bands appear across the leaflets (plate 1,C), and later change to amber-yellow or pale orange. A reliable symptom in a later stage of the disease is green islands 
in the lemon-yellow areas (plate $1, D$ ) of the outer leaves. Sometimes the green areas are surrounded by chlorotic rings, resembling ringspot (plate $1, E$ ). In the more advanced stages of the disease, the leaflets may show green and yellow zigzag bands and many small green islands (plate $1, F)$. Celery calico has been found in all of the large celery districts of California.

Celery Crinkle-Leaf.-Another virus disease of celery has been named "crinkle-leaf mosaic." The first symptom of the disease on the youngest

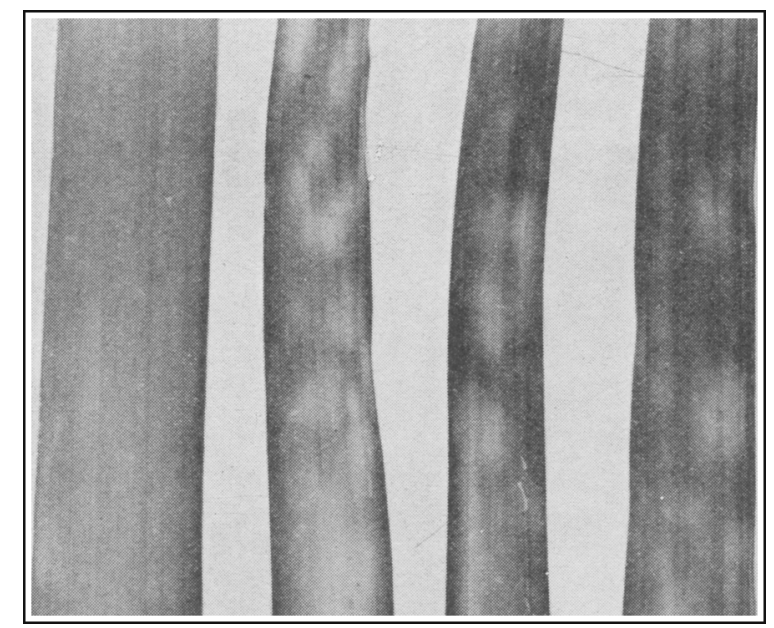

Fig. 1.-Petioles from celery (Apium graveolens var. dulce) naturally infected with celery yellow spot: left, petiole from a healthy celery plant; right, three petioles showing white spots (Milpitas, October 17, 1935).

leaves is a clearing of the veinlets, sometimes restricted to the basal portion of the leaflets (plate 2, $C$ ). The most conspicuous symptom which develops later is crinkle leaflets with green islands or blisterlike elevations (plate 2, D). Young infected plants are stunted, and in the later stages of the disease, the leaves turn yellow and frequently the plant dies. This disease has been found in the celery districts of the Santa Clara Valley.

Celery Yellow Spot.-The name "yellow spot" is proposed for a virus disease of celery that is characterized by small irregular chlorotic areas on the leaves (plate $2, A$ ) and yellow stripes or bands along the veins (plate $2, B$ ). The petioles frequently show white spots (fig. 1), and when the epidermis is removed brown specks may be seen along the veins (plate $3, E)$. This disease occurs in the Santa Clara, Salinas, and Sacramento valleys. 
Celery Yellows.-The virus of celery yellows has been demonstrated to be identical with that of California aster yellows. Both diseases have been discussed in a previous paper (28).

Spotted Wilt.-The following description of the symptoms of spotted wilt on celery has been contributed by M. W. Gardner :

Spotted wilt, a disease caused by a thrips-transmitted virus attacking a wide range of truck crops and ornamentals especially in the coastal districts, is very destructive in its effects on celery. Infected celery plants show numerous small yellow spots on

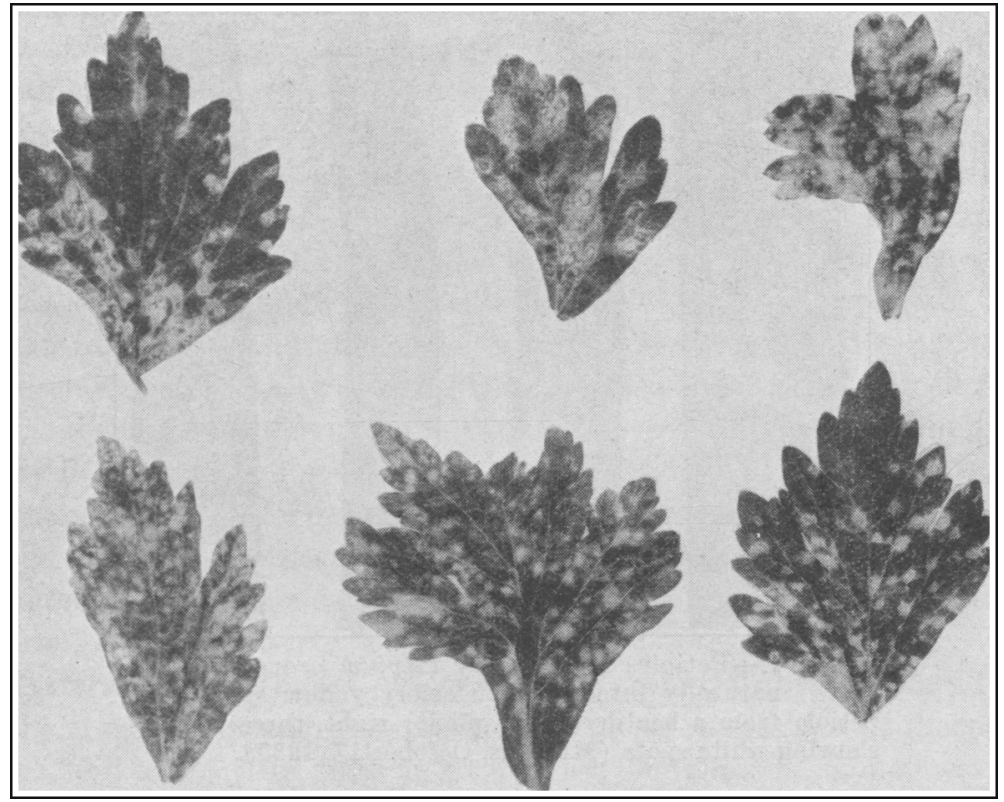

Fig. 2.-The spotted-wilt virus produces numerous yellow spots on the celery leaves; later these spots become brown and dead at the center (San Pablo, September 18, 1934, courtesy of M. W. Gardner).

the blades of the older leaves (fig. 2). These spots soon become brown and dead at the center. More serious, however, are large pockets of brown dead tissue, often entirely internal, which occur in the stalks of the older leaves (fig. 3). These leaf stalk lesions may become visible as sunken brown patches and eventually may kill the entire leaf. Frequently the dead areas are invaded by rot-producing organisms.

Plants infected early are greatly stunted and never become marketable. Plants infected late must be carefully examined and heavily pruned to remove all of the stalks that show dead spots, which are, needless to say, extremely objectionable to the consumer. Often the internal dead patches are difficult to detect without slicing the stalk with a knife.

Gardner, Tompkins, and Whipple (11) report that spotted wilt is most prevalent and severe in the cooler coastal districts of California, par- 
ticularly where truck crops or ornamentals are grown to some extent throughout the year.

Sugar-Beet Curly Top.-The varieties Golden Self-blanching, Giant Pascal, and White Plume celery have been experimentally infected with the virus of sugar-beet curly top (28), but celery has not been found naturally infected up to the present time.

Poison-Hemlock Ringspot.-Celery has been experimentally infected with poison-hemlock ringspot. The symptoms on celery are character-

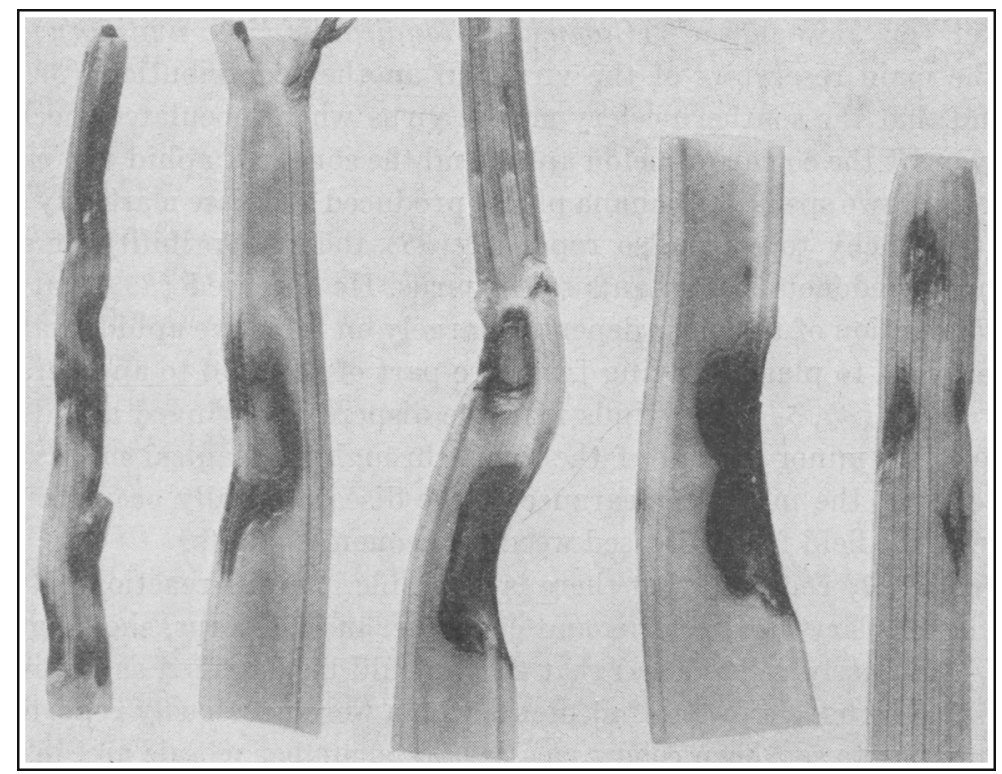

Fig. 3.-Spotted wilt in celery is characterized by large pockets of dead tissue in the leaf stalks, sometimes conspicuous like these, sometimes entirely internal and difficult to detect without slicing the stalks with a knife (San Pablo, December 4,1935 , courtesy of M. W. Gardner).

ized by small chlorotic rings enclosing green spots (plate $2, E$ ) or by a series of chlorotic dots and dashes encircling irregular green areas. The chlorotic ring may be surrounded by a green line and both are sometimes embedded in a pale-yellow halo. Sometimes large, green, irregular areas are surrounded by alternating yellow and green lines (plate $2, F$ ).

Southern Celery Mosaic (Celery Virus 1).-Foster and Webber (9) were first to describe celery mosaic in Florida. Southern celery mosaic has been reported by Doolittle and Wellman (5) from Florida and by Wellman (38) from Cuba. Plants having apparently identical symptoms have been found by these scientists in California, Wisconsin, Ohio, 
and New York (5). Doolittle and Wellman (5) reported the transmission of the southern-celery-mosaic virus to cucumbers by the cotton or melon aphid (Aphis gossypii Glover) and by mechanical inoculation. Wellman $(36,40)$ came to the conclusion from his host-range studies and experimental results on the properties of the virus, that the virus of southern celery mosaic is new and distinct from that of cucumber mosaic.

Wellman published a number of other papers on southern celery mosaic. He reported (35) the control of southern celery mosaic by the eradication of the monocotyledonous host commonly known as "day flower" or "dew flower" (Commelina longicaulis $=$ C. nudiflora), one of the main reservoirs of the virus. In another contribution (37), he found that the southern-celery-mosaic virus when inoculated mechanically or by the cotton or melon aphid and the corn-leaf aphid (A. maidis Fitch) in two species of banana plants produced a disease markedly similar to bunchy top. He also reported (38) the susceptibility of other monocotyledonous host plants to the virus. He observed (39) that field dissemination of the virus depended largely on infective aphids walking from plant to plant or flying from one part of the field to another, and correlated $(38,54)$ east winds with the dispersal of winged aphids. $\mathrm{He}$ reported a minor spread of the virus through mechanical means, and stated that the initial appearance of the disease usually occurs on the edge of the field from diseased weeds or economic plants.

Price (23) reported that there is a specific immune reaction between southern-celery-mosaic virus and cucumber-mosaic virus, showing that they are closely related and that they should be classified as strains of the same virus. He found that plants which were previously reported to be immune to southern celery mosaic and cucumber mosaic are, in fact, susceptible. These findings suggest that the host range of cucumber mosaic and celery mosaic may eventually be found to be identical. The virus causing southern celery mosaic should be designated as a strain of cucumber mosaic.

Cucumber Mosaic (Cucumber Virus 1).-A celery mosaic which causes a pronounced filiformity of the leaflets has been described by Poole (22) in New Jersey, Harvey (13) in Minnesota, and Elmer (6) in Iowa. Wellman (36) "was convinced that Poole, Harvey, and Elmer were working with common cucumber mosaic (cucumber virus 1 Doolittle [3]) on celery." Johnson and Grant (15) infected celery with cucumber mosaic in their studies on the properties of plant viruses from different host species.

Doolittle (3) reported the transmission of the cucumber-mosaic virus by the cotton or melon aphid (Aphis gossypii) and by mechanical inocu- 
lation to celery. Wellman (36) states that the leaves on celery infected with cucumber mosaic, after about a month, showed filiformities and raised blisterlike areas following a mild mottling.

Distribution of Celery Mosaic.-Numerous other references of the occurrence of celery mosaic in the United States have appeared in the literature, especially in the Plant Disease Reporter, but in most cases the identification of the virus cannot be determined from these limited reports. "Celery mosaic" has been recorded from the following states :

California $(5,8,45,48,49,56,58,59)$ (western celery mosaic [16, 21], celery calico, and celery yellow spot [16] have been specifically recorded)

Connecticut $(51,56,58)$

Florida $(44,47,49,51,52,53,55)$, Chicago market celery $(57,58)$

Indiana $(10,42,43)$

Iowa $(47,48,58)$

Massachusetts (41)

Michigan (58)

Minnesota (43)

New Jersey $(43,47)$

New York, market celery $(5,45,47,48,55,56,58)$

Ohio $(5,46,48)$

Utah (50)

Wisconsin (5)

Gigante (12) described the symptoms of a celery mosaic in Italy. Light-green or yellowish chlorotic areas and dark-green patches occurred on the leaves, which were wrinkled, with irregular midribs, greatly swollen underneath. Light-later dark-brown-elongated areas were present on the stalks, which curved over, forming an arc. The virus was transmitted by juice inoculations and by the aphid Cavariella pastinaceae Linn. from diseased to healthy celery and also to pumpkin.

\section{MATERIALS AND METHODS}

Source of Virus.-The source of the western-celery-mosaic virus used in the work on host range and property studies was naturally infected celery plants obtained in the Santa Clara Valley. The virus was retained by repeated mechanical inoculation and aphid transmission to celery.

Celery Extract.-In the preparation of juice from the leaves from western-celery-mosaic plants, the leaves were washed in distilled water and either ground to a pulp in a sterilized food chopper or in a mortar. The pulp was then placed in two layers of cheesecloth and the juice pressed out into a sterilized beaker or pan by hand. 
Centrifugation.-In the work on filtration, the extracted juice was centrifuged for 1 hour at a speed of 3,500 revolutions per minute.

Mechanical Inoculation.-The method of mechanical inoculation used is that described by Rawlins and Tompkins (24). Shortly after inoculation, the carborundum and inoculum was washed from the leaves with water. The virus extract was usually inoculated in 5 healthy celery plants with each preparation.

Collecting and Rearing Aphids.-Various methods were used in determining the presence of aphids on celery. High populations of aphids were rarely found on celery under natural conditions during the summer. When the population of aphids was low on diseased celery shipped by scientists and growers, celery leaves were removed from the plants and shaken over black sateen; the aphids which dropped from the foliage were then transferred with a moistened camel's-hair brush to potted healthy celery plants enclosed in cages. The method finally adopted to secure both foliage and root-feeding aphids was to pot diseased celery plants obtained from the field, enclose them in cages, and allow the aphids to multiply.

A number of requests have been received from plant pathologists for a description of the methods used in rearing aphids in the greenhouse. Foliage-feeding aphids reared on celery grown in the greenhouse will die if transferred to celery with hardened leaves grown out of doors during late autumn and winter. Celery grown out of doors when kept in cages in the greenhouse will develop tender inner leaves on which the aphids can be reared. Low mortality of aphids occurred on celery grown in the greenhouse.

Mixed populations of different species of aphids or parasitized or fungus-diseased aphids were frequently collected in celery fields. Each species of aphid in a mixed population was removed with a camel's-hair brush under a binocular microscope. Young aphids were selected in an attempt to eliminate parasitized or fungus-diseased aphids. When a small braconid parasite, Lysiphlebus testaceipes (Cresson) emerged from the aphids, all aphids in the cage became parasitized. All parasites and parasitized or "mummied" aphids were removed from the cages. High humidity in the greenhouse and excessive soil moisture in the pots stimulate fungus diseases of the aphids. To eliminate high humidity and high temperatures in the greenhouse, the upper and lower vents were kept open day and night during the summer, which gave plenty of air circulation, and to lower the temperature, all glass of the greenhouse was whitewashed. The surface of the soil in the pots was covered with about an inch of dry coarse sand. Each pot was placed in a clay 
saucer and the saucers were watered whenever they became dry. The cages used have been described and figured in a previous paper (29).

Aphids will usually die if placed on celery just after spraying with nicotine sulfate (Black Leaf 40) or Ortho Nursery Volck (or a combination of the two, or after fumigating with Nico-Fume tobacco-paper insecticide. Sprayed or fumigated plants can be used a few days after treatment, with the exception of plants sprayed with Ortho Nursery Volck, which must be thoroughly washed from the leaves with cotton swabs immersed in water.

In the greenhouse, control measures must be adopted against the Argentine ant (Iridomyrmex humilis Mayr), which enters the cages and carries away the aphids. Tree tanglefoot was applied to the legs below the tops of the tables on which rested the potted plants enclosed in cages.

One experience in which many colonies of aphids were lost may be worthy of mention. Creosote was applied to new floors in the greenhouse with the vents closed during the night; by the next morning most of the aphids had been killed by the fumes. The creosote, however, acted as an effective repellent for the Argentine ant for a long time.

Production of Noninfective Aphids.-In order to obtain noninfective aphids for experimental purposes, wingless mature aphids were transferred from western-celery-mosaic plants to healthy celery. The next day the offspring from the mature forms were transferred to a second healthy celery plant or to a plant immune to the disease.

Methods of Transferring Aphids.-Both noninfective and infective aphids were transferred, whenever a new food supply was necessary, by cutting off and placing the leaves with high populations of aphids on the inner or youngest leaves of another plant. If an accurate count of the number of aphids was desired, the aphids were transferred from plant to plant with a moistened camel's-hair brush. The mortality as the result of the transfers was low when the aphids were first induced to withdraw their mouth parts from the food plant by gently touching them on the abdomen with a camel's-hair brush.

\section{SYMPTOMATOLOGY}

The most striking symptoms of western celery mosaic on small plants as seen in the field are the yellowed foliage, stunting of the plant, shortening of the central younger petioles, and horizontal instead of upright position of the outer petioles, which gives the top of the plant a flattened appearance. An examination of the foliage of celery-mosaic plants in the Fog Belt shows speckling of green and yellow or mottling on the younger leaves; but in the hot interior regions such as the Sacramento Valley, 
these symptoms are often absent during the summer. As the disease progresses, the older leaves sometimes show rusty or brown, necrotic, sunken areas on the upper surface of the leaves. The petioles sometimes show white streaks or spots.

The first symptom of western celery mosaic observed under a binocular microscope on white varieties of celery infected either by aphids or by mechanical inoculation is a clearing of the veins and veinlets and puckering of the youngest leaves (plate $3, C, D$ ), but with the naked eye the veinlets appear white. The cleared veinlets occasionally appear within 4 days on small plants after inoculation, but on larger plants usually require from 1 to 2 weeks in the greenhouse and from 10 to 16 days or longer out of doors during the summer. The interspaces between the veinlets are green, but later some of the interspaces turn yellow, which causes a mottling (plate $4, A, B, C$ ). The older leaves may show speckling and bands of green (plate $4, D$ ) or most of the margin may be green (plate $4, E$ ) or yellow (plate $4, F$ ).

As the disease progresses, rust-colored necrotic specks which later turn brown may develop on the upper surface of the outer leaves (plate 5, $A$ ). Brown necrotic spotting developed in from 1 to 2 weeks after the cleared veinlets appeared when inoculated plants were kept out of doors during the summer, but this symptom rarely developed in the greenhouse. The brown specks enlarge to necrotic sunken areas and, as they become more abundant, frequently coalesce to form streaks or irregular patterns along the margins, which may spread over most of the leaflets (plate $5, B$ ).

In the advanced stage of the disease, the leaflets are narrow, twisted, and cupped (fig. 4). The petioles sometimes show longitudinal white streaks (plate $3, B$ ) alternating with green streaks, or more often the petioles show white spots (plate $3, A$ ).

The symptoms of the disease on Utah celery, a green variety, are not as conspicuous in the field as on the white varieties. Frequently the youngest leaves are yellow with faint mottling, and often the leaflets are twisted and cupped. The outer leaves may show mottling.

A comparison of the symptoms of the disease on naturally and experimentally infected celery in early and late stages indicates that this disease is identical in all of the localities shown in table 13 (pp. 522-24).

Differentiating from Southern Celery Mosaic.-The early symptoms of southern celery mosaic on the leaves are similar to those of western celery mosaic. Wellman (40) describes the former as follows :

The inoculation studies have shown that the first symptom of southern celery mosaic on young leaves is a faint vein-clearing pattern, which occurs under the most favorable greenhouse conditions in about 6 days, although it may take 10 to 40 days 
for it to appear in the field. The vein-clearing pattern on leaves usually changes in about 10 days to a brilliant yellow mottling that, about a month later, is not so marked. Secondary systemic symptoms in older leaves result in yellowish oak-leaf patterns which in some cases take the form of continuous zigzag bands across the leaf lamina, and in other cases are markedly irregular and may break up into chlorotic blotches and spots.

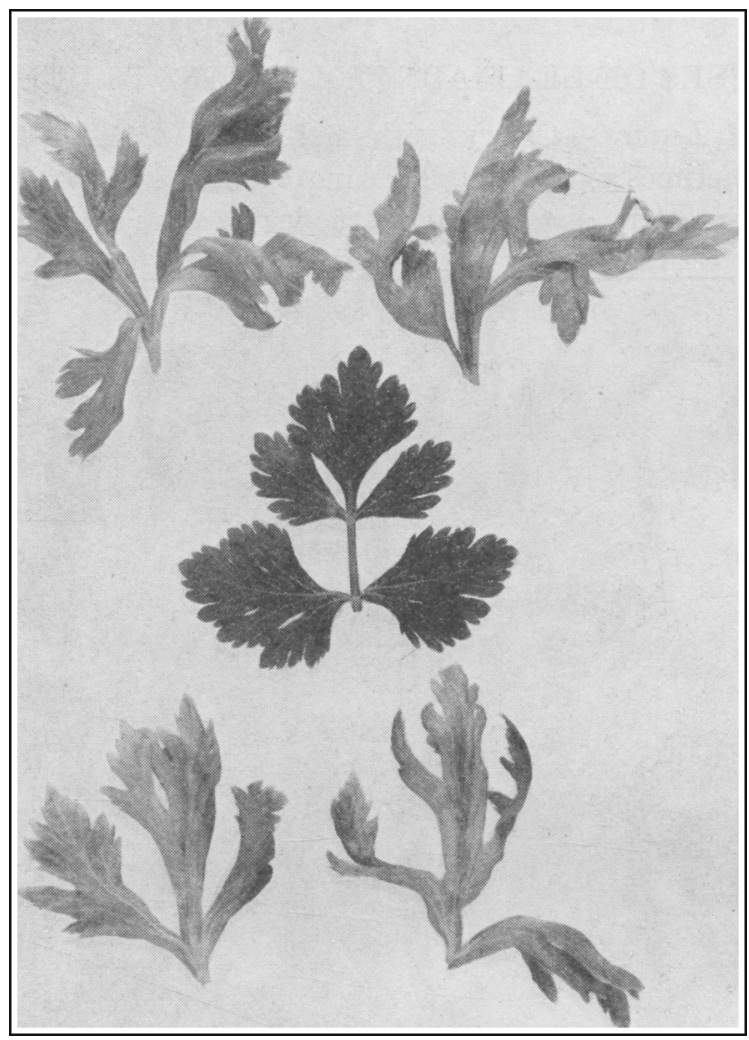

Fig. 4.-Center, celery leaflets from a healthy plant; grouped around it are four celery leaflets from a plant naturally infected with western celery mosaic showing narrow, twisted or cupped leaflets (Gardena, July 1, 1935).

In the description of symptoms of southern celery mosaic, no mention is made of rust-colored or brown necrotic specks, streaks, or irregular patterns on the upper surface of the older leaves, which are characteristic of western celery mosaic after secondary systemic symptoms developed.

As the disease progresses, buff, almost salmon-colored, water-soaked spots and sunken streaks develop on the petioles of southern-celery-mosaic plants, and the vascular system of the petioles and leaf rachises is 
often discolored or darkened throughout. The dark or streaked petioles later become brown, shriveled, and necrotic, and finally decay. These symptoms have never been observed on western-celery-mosaic plants, but rather the petioles sometimes show white streaks or spots. When a celery plant is infected with both western celery mosaic and spotted wilt, severe necrosis of the petioles occurs, but necrosis is caused by the virus of spotted wilt.

\section{CAUSES OF LEAF ABNORMALITIES IN CELERY}

Club-shaped Leaves.-Celery with malformed or club-shaped leaves (fig. 5), sometimes with shoots growing below the crown (fig. 6), have been found in celery districts where the leaves were cut back in the seed

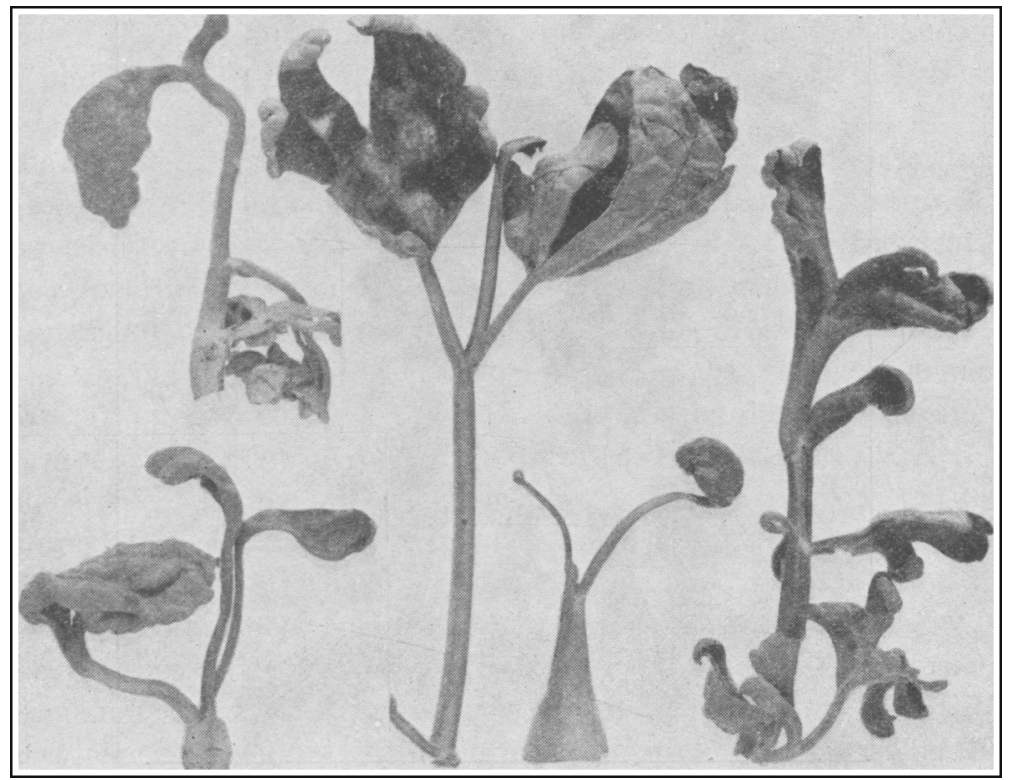

Fig. 5.-Malformed or club-shaped celery leaves developed by cutting back the crown or by improper transplanting so that the root is curved up in the soil (Terminus, San Joaquin Valley, September 17, 1936).

bed. According to the opinion of celery growers, these abnormalities are caused by cutting back the crown or by improper transplanting so that the root is curved up in the soil. Sometimes these abnormal celery plants were infected with western celery mosaic (plate $6, C$ ), as was demonstrated by juice inoculation and by transmission of the virus by the cotton or melon aphid (Aphis gossypii); but the malformed leaves were caused by cultural conditions. 
Linear Leaflets.-Celery was sometimes found under natural conditions with narrow or linear leaflets (plate $6, E$ ), resembling those caused by cucumber mosaic. Occasionally these abnormal celery plants were infected with western celery mosaic, but not with cucumber mosaic, as was

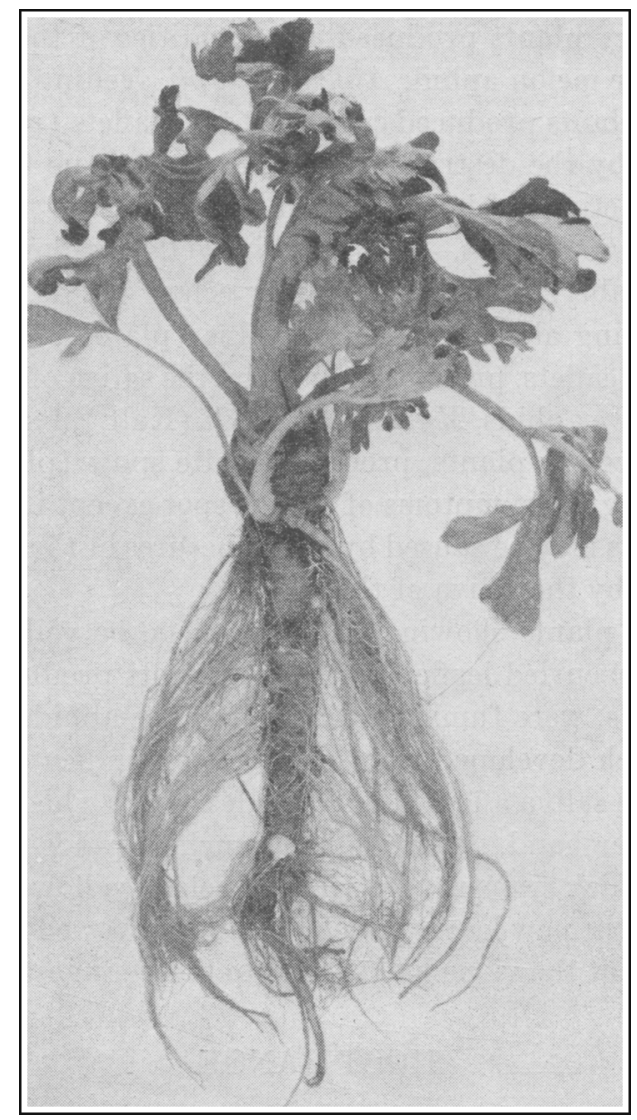

Fig. 6.-Celery plant showing abnormal leaves and with shoot growing below the crown caused by cutting back the crown (Terminus, San Joaquin Valley, September 17, 1936).

demonstrated by juice inoculation. On rare occasions healthy celery plants may develop narrow leaflets (plate $6, F$ ). Celery experimentally infected with western celery mosaic sometimes develop abnormal leaflets; for example, a portion of one leaflet may be narrow (plate $6, B$ ) or all leaflets may be narrow with the exception of the apical leaflet (plate $6, A)$. On one occasion a celery plant was found on which the leaflets 
showed blisterlike pustules (plate $6, D$ ) resembling those caused by cucumber mosaic on celery, but all attempts to transmit the virus to healthy celery and cucumber plants by juice inoculations were failures. Aphid transmission was not tested.

Curling of Leaflets.-Different species of noninfective aphids feeding on healthy celery plants produced abnormalities of the leaflets. Noninfective cotton or melon aphid, Aphis gossypii, feeding on the foliage of healthy celery plants produced curling of the leaflets (plate $7, A$ ), which may be caused by the destruction of some leaf tissue to the phloem by the feeding punctures of large number of aphids.

Yellowing and Chlorosis.-Noninfective yellow willow aphids, Cavariella capreae (Fabr.), feeding on healthy celery plants, produced a pronounced yellowing along the cleared veins (plate $7, B$ ) and a marked chlorosis of the leaflets, probably caused by the saliva of the aphids. Noninfective foxglove aphids, Myzus convolvuli (Kalt.), feeding on the leaflets of healthy celery plants, produced white spots (plate $7, C, D$ ), the latter resembling the symptoms of yellow spot except in color. The curling of the leaflets may be caused by the punctures of the mouth parts and the white spots by the saliva of the aphids.

When celery plants showing curled leaflets, or yellowing along the cleared veins, or curled leaflets with white spots produced by the three species of aphids, were fumigated and all of the aphids were killed, the new leaves which developed were normal; this indicated that the toxic substance in the saliva affected only the leaves on which the aphids had fed. On the other hand, when the honeysuckle aphids (Rhopalosiphum melliferum), which transmit the virus of celery yellow spot, were killed by fumigation, the new leaves which developed showed the yellow spots; this indicates that the virus had spread to the youngest leaves.

\section{HOST RANGE}

Natural Infection.-The following economic plants have been found to be naturally infected with western celery mosaic up to the present time. The virus was recovered by inoculation of extracted juice from these host plants into healthy celery.

Celeriac (Apium graveolens var. rapaceum)

Carrot (Daucus Carota var. sativa), varieties Chantenay, Chantenay Red Cored, Danvers Half Long, Imperator, and Short Top

Experimental Infection.-The following plants-all economic-of the family Umbelliferae, are the only ones other than celery which have been infected thus far. 
Large Smooth Prague celeriac (Apium graveolens var. rapaceum)

Dill (Anethum graveolens)

Curled chervil (Anthriscus Cerefolium)

Caraway (Carum carvi)

Coriander (Coriandrum sativum)

Carrot (Daucus Carota var. sativa) ; white varieties: Short White, White Mastodon, and White Belgian; yellow variety: Yellow Belgian; orange varieties: Chantenay, Chantenay Red Cored, Danvers Half Long, Early Scarlet Horn, French Forcing, Imperator, Long Orange, Nantes, and Oxheart, or Guerande

Single or Plain parsley (Petroselinum hortense)

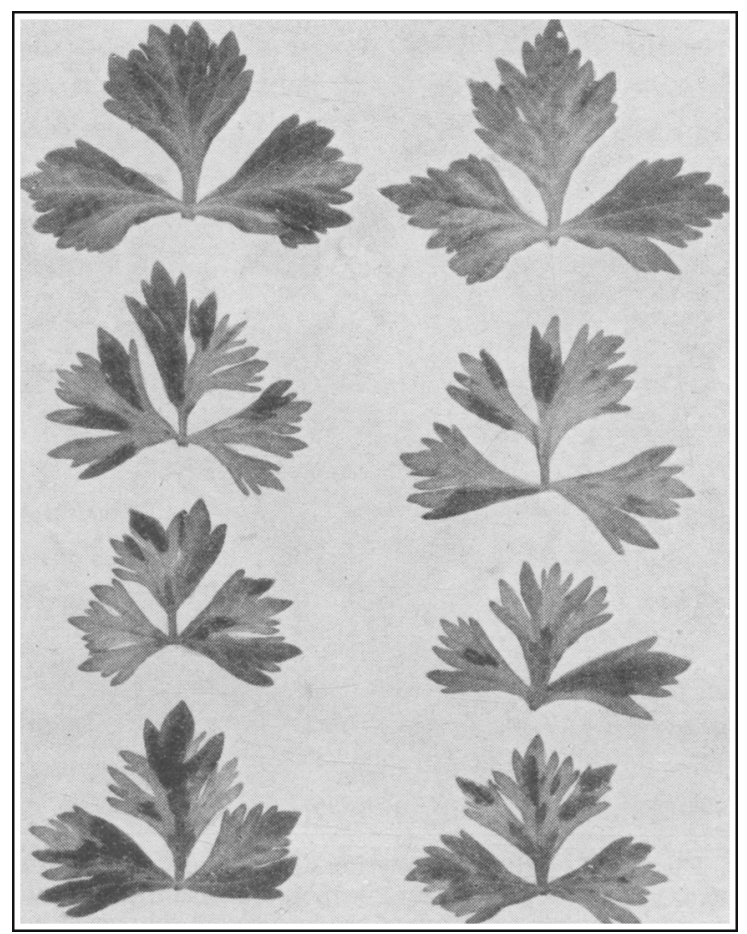

Fig. 7.-Large Smooth Prague celeriac (Apium graveolens var. rapaceum) ; upper row, leaflets from a healthy plant; others from a plant infected with western celery mosaic by the rusty-banded aphid (Aphis ferrugineastriata), showing blotches which were deep green scattered in the chlorotic areas of the leaflets.

Recovery of Virus. - The virus was recovered from the experimentally infected host plants by inoculation of extracted juice or by previously noninfective rusty-banded aphids (Aphis ferruginea-striata Essig) into healthy celery. All inoculated economic plants and weeds which failed 
to show symptoms of the disease were also tested for the recovery of the virus by both methods.

Symptoms.-The symptoms of western celery mosaic on different host plants are, briefly, as follows :

Large Smooth Prague celeriac: The first symptom of the disease observed under a binocular microscope is a clearing of the veins, accompanied later by chlorosis along the veins, followed by mottling. The

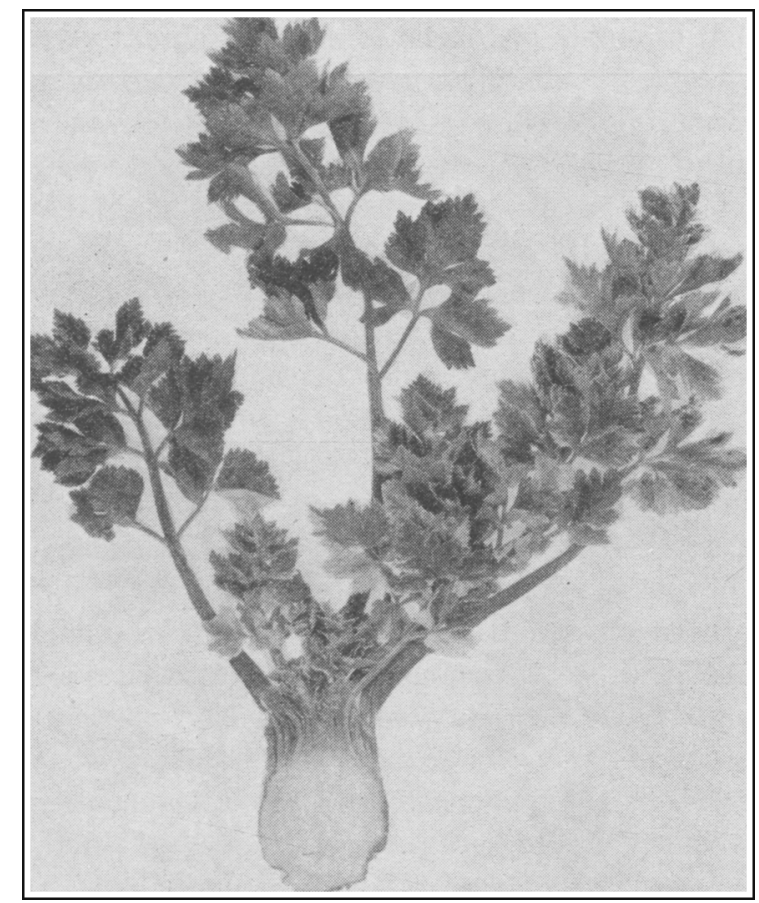

Fig. 8.-Longitudinal section of celeriac (Apium graveolens var. rapaceum) naturally infected with western celery mosaic, showing mottling of the leaves and shortened inner or central petioles (Alvarado, December 19, 1935).

mosaic pattern consists of deep-green blotehes scattered in chlorotic areas of the leaflets (fig. 7). Naturally infected celeriac showed mottled leaves and shortened inner or central petioles (fig. 8).

Dill : A single plant was infected with western celery mosaic by the rusty-banded aphid, and the only symptom of the disease observed was chlorotic secondary shoots arising from the axil of the leaves.

Curled chervil : The first symptom of the disease is a yellowing along the veins, followed by chlorotic spotting of the inner or youngest leaves. 
In the later stage of the disease, the outer leaves show brown spotting followed by necrosis (plate $5, F$ ). The leaflets finally turn yellow and die.

Coriander : The earliest symptom of the disease was a clearing of the veinlets (plate 8) on the youngest leaves, followed later by a mottling of the older leaves (plate 8), which frequently became cupped outward. The stems were chlorotic, and infected plants were stunted.

Carrot: Plants infected with western celery mosaic by the rustybanded aphid showed chlorotic areas on the youngest leaflets (plate 5,C) followed by mottling (plate $5, D, E$ ).

Single or Plain parsley : Fifty plants were inoculated mechanically or by the rusty-banded aphid with the virus of western celery mosaic, but only 10 plants developed mild symptoms of the disease. A slight chlorosis appeared along the midrib and lateral veins and spread as blotches over the leaflets. Frequently only the leaflets of a few outer leaves showed these symptoms. No cleared veinlets were noted on the inner or youngest leaves.

\section{INOCULATION EXPERIMENTS}

Extracts from Diseased Carrots.-In a previous experiment, Severin and Freitag (31) reported that the curly-top virus could be transmitted more successfully to healthy beet seedlings by previously noninfective nymphs fed on diseased beet-root juice than by means of those fed on leaf juice. A somewhat similar experiment was performed with the extract from the leaves and roots of mosaic carrots inoculated with carborundum in healthy celery plants. The juice was expressed from the leaves and roots of 9 varieties of carrots naturally or experimentally infected with western celery mosaic. In each test the juice from each variety of carrot was expressed from the leaves and roots and inoculated into healthy celery plants.

The results obtained are shown in table 2 . According to these data, the average percentage of infections was higher with diseased root juice, 76.0 and 79.0 per cent, from naturally and experimentally infected carrots respectively, as compared with 36.0 and 54.0 per cent with leaf juice. Table 2 shows that 6 of 10 preparations from the leaves and all 10 preparations from the roots of naturally infected carrots were infectious, and 18 of 20 preparations from the leaves and 19 of 20 preparations from the roots of experimentally infected carrots were infectious.

Extract from Diseased Single or Plain Parsley.-An experiment was conducted to determine whether the virus of western celery mosaic could be more readily recovered by mechanical inoculation or by means of noninfective aphids from Single or Plain parsley. Fifteen small plants were inoculated with the virus by the rusty-banded aphid. Three plants 
developed symptoms of the disease and 12 plants failed to show symptoms on the leaves. The virus was recovered from only 7 of the 15 plants inoculated; the results obtained in the recovery of the virus by mechanical inoculation and by aphids are shown in table 3. According to these results, the virus was recovered from 6 plants by mechanical inoculation and from 2 plants by aphids. The 7 plants from which the virus was re-

\section{TABLE 2}

Comparative Infectiousness of Leaf Juice and Root Juice of Carrots NatuRALLY AND EXPERIMENTALLY INFECTED WITH Western Celery MOSAIC

\begin{tabular}{|c|c|c|c|c|c|c|c|c|c|c|}
\hline \multirow{3}{*}{$\begin{array}{l}\text { Type of infection } \\
\text { and variety }\end{array}$} & \multicolumn{4}{|c|}{$\begin{array}{l}\text { Preparations used as } \\
\text { sources of virus }\end{array}$} & \multicolumn{6}{|c|}{ Plants inoculated } \\
\hline & \multicolumn{2}{|c|}{$\begin{array}{l}\text { Leaf } \\
\text { juice }\end{array}$} & \multicolumn{2}{|c|}{$\begin{array}{l}\text { Root } \\
\text { juice }\end{array}$} & \multicolumn{2}{|c|}{$\begin{array}{l}\text { With leaf } \\
\text { juice }\end{array}$} & \multicolumn{2}{|c|}{$\begin{array}{c}\text { With root } \\
\text { juice }\end{array}$} & \multicolumn{2}{|c|}{$\begin{array}{l}\text { Per cent } \\
\text { infected }\end{array}$} \\
\hline & $\begin{array}{c}\text { Num- } \\
\text { ber } \\
\text { tested }\end{array}$ & $\begin{array}{l}\text { Num- } \\
\text { ber } \\
\text { infec- } \\
\text { tious }\end{array}$ & $\begin{array}{c}\text { Num- } \\
\text { ber } \\
\text { tested }\end{array}$ & $\begin{array}{l}\text { Num- } \\
\text { ber } \\
\text { infec- } \\
\text { tious }\end{array}$ & $\begin{array}{l}\text { Num- } \\
\text { ber } \\
\text { inoc- } \\
\text { ulated }\end{array}$ & $\begin{array}{l}\text { Num- } \\
\text { ber } \\
\text { in- } \\
\text { fected }\end{array}$ & $\begin{array}{l}\text { Num- } \\
\text { ber } \\
\text { inoc- } \\
\text { ulated }\end{array}$ & $\left|\begin{array}{c}\text { Num- } \\
\text { ber } \\
\text { in- } \\
\text { fected }\end{array}\right|$ & $\begin{array}{l}\text { Leaf } \\
\text { juice }\end{array}$ & $\begin{array}{l}\text { Root } \\
\text { juice }\end{array}$ \\
\hline Natural & & & & & & & & & & \\
\hline Chantenay & 2 & 0 & 2 & 2 & 10 & 0 & 10 & 9 & 0.0 & 90.0 \\
\hline Chantenay Red Cored. & 2 & 1 & 2 & 2 & 10 & 3 & 10 & 7 & 30.0 & 70.0 \\
\hline Danvers Half Long..... & 2 & 1 & 2 & 2 & 10 & 4 & 10 & 5 & 40.0 & 50.0 \\
\hline Imperator $\ldots \ldots \ldots \ldots \ldots \ldots$ & 2 & 2 & 2 & 2 & 10 & 8 & 10 & 10 & 80.0 & 100.0 \\
\hline Short Top $\ldots \ldots \ldots \ldots \ldots \ldots$ & 2 & 2 & 2 & 2 & 10 & 3 & 10 & 7 & 30.0 & 70.0 \\
\hline Total, all varieties. & 10 & 6 & 10 & 10 & 50 & 18 & 50 & 38 & 36.0 & 76.0 \\
\hline \multicolumn{11}{|l|}{ Experimental } \\
\hline Long Orange. & 5 & 5 & $\mathbf{5}$ & 5 & 25 & 18 & 25 & 24 & 72.0 & 96.0 \\
\hline Short White... & 5 & 4 & 5 & 4 & 25 & 13 & 25 & 15 & 52.0 & 60.0 \\
\hline White Belgian..... & 5 & 4 & 5 & 5 & 25 & 8 & 25 & 24 & 32.0 & 96.0 \\
\hline Yellow Belgian ............... & 5 & 5 & 5 & 5 & 25 & 15 & 25 & 16 & 60.0 & 64.0 \\
\hline Total, all varieties. . . . . . . . . & 20 & 18 & 20 & 19 & 100 & 54 & 100 & 79 & 54.0 & 79.0 \\
\hline
\end{tabular}

covered failed to show visible symptoms of the disease on the leaves. In this experiment, the virus was not recovered in either way from the 3 plants which showed symptoms of the disease. In other tests (not included in the table) the virus was recovered by both methods. It is evident that the virus was more readily recovered from Single or Plain parsley by mechanical inoculation than by aphids and also that some plants were symptomless carriers of the disease.

Attempts to Infect Cucumber Plants by Mechanical Inoculation.Since celery has been reported to be susceptible to cucumber mosaic (cucumber virus 1) and southern celery mosaic is a strain of cucumber mosaic, attempts were made to transmit western celery mosaic to cucumber plants by mechanical inoculation of the expressed juice from nat- 
urally infected celery collected in many different celery districts in California. In each test the juice was extracted from at least 5 naturally infected celery plants and inoculated in from 5 to 15 healthy celery and in the same number (with three exceptions) of White Spine cucumber plants. Frequently a celery plant was naturally infected by both western celery mosaic and celery calico, but the symptoms of celery calico were not conspicuous after secondary systemic symptoms of western celery mosaic developed on the older leaves. The expressed juice from a plant

\section{TABLE 3}

Recovery of Western-Celert-Mosaic Virus by Mechanical Inoculation ANd By Rustry-Banded ApHID, Aphis ferruginea-striata ESSIG, FROM SINGLE or Plain Parsley

\begin{tabular}{|c|c|c|c|c|}
\hline \multirow{3}{*}{$\begin{array}{l}\text { Single or } \\
\text { Plain } \\
\text { parsley } \\
\text { plant } \\
\text { No. }\end{array}$} & \multirow{2}{*}{\multicolumn{2}{|c|}{$\frac{\begin{array}{c}\text { Mechanically } \\
\text { inoculated }\end{array}}{\text { Celery plants }}$}} & \multirow{2}{*}{\multicolumn{2}{|c|}{$\frac{\begin{array}{c}\text { Inoculated by } \\
\text { Aphis ferruginea-striata }\end{array}}{\text { Celery plants }}$}} \\
\hline & & & & \\
\hline & Inoculated & Infected & Inoculated & Infected \\
\hline 1 & 5 & 3 & 5 & 1 \\
\hline 2 & 5 & 0 & 5 & 1 \\
\hline 3 & 5 & 4 & 5 & 0 \\
\hline 4 & 5 & 4 & 5 & 0 \\
\hline 5 & 5 & 2 & 5 & 0 \\
\hline 6 & 5 & 1 & 5 & 0 \\
\hline 7 & 5 & 1 & 5 & 0 \\
\hline Total & 35 & 15 & 35 & 2 \\
\hline Percentage & .. & 48.9 & $\ldots \ldots$ & 5.7 \\
\hline
\end{tabular}

containing the two viruses inoculated in healthy celery plants developed the typical symptoms of western celery mosaic on the inner leaves and celery calico on the outer leaves.

The results of inoculating healthy celery and cucumber plants with the extract from naturally infected celery plants are shown in table 4. Of the healthy celery plants inoculated with the extract from naturally infected celery collected in 23 celery districts, 53.8 per cent developed symptoms of western celery mosaic, while all of the cucumber plants inoculated remained healthy. Results of attempts to transmit the virus to cucumber plants by means of aphids are discussed on pages 521, 525-26.

When cucumber plants were inoculated with the extract from a naturally infected celery plant containing the two viruses, calico symptoms developed. When celery was inoculated with the expressed juice from these cucumbers, typical symptoms of celery calico developed on the 
outer leaves but no symptoms of western celery mosaic appeared on the inner leaves. It is evident that the virus of celery calico was separated out of a virus complex in naturally infected celery by passage through cucumber and back to celery; the virus of western celery mosaic was filtered out.

\section{TABLE 4}

Attempts to Infect Cucumber Plants with Extract from Celery Infected with Western Celery Mosaic Collected in Many

Celery Districts of California

\begin{tabular}{|c|c|c|c|c|c|c|}
\hline \multicolumn{2}{|c|}{ Source of virus } & \multirow{2}{*}{$\begin{array}{c}\text { Date } \\
\text { diseased } \\
\text { celery } \\
\text { collected }\end{array}$} & \multicolumn{2}{|c|}{$\begin{array}{l}\text { Control tests on } \\
\text { celery plants }\end{array}$} & \multicolumn{2}{|c|}{ Cucumber plants } \\
\hline County & District & & Inoculated & Infected & Inoculated & Infected \\
\hline \multirow{2}{*}{ Sacramento. . } & (Perkins.... & Aug. 10 & 5 & 5 & 5 & 0 \\
\hline & $\left\{\begin{array}{c}\text { Sacramento } \\
\text { Pocket..... }\end{array}\right.$ & Sept. 10 & 5 & 5 & 5 & 0 \\
\hline Yolo..... & West Sacramento & Aug. 10 & 5 & 3 & 5 & 0 \\
\hline Contra Costa....... & San Pablo........ & July 26 & 5 & 1 & 5 & 0 \\
\hline \multirow[t]{3}{*}{ San Mateo.......... } & Redwood City... & July 8 & 5 & 5 & 5 & 0 \\
\hline & (Palo Alto.. & $\{$ April 29 & 5 & 1 & 5 & 0 \\
\hline & & May 18 & 5 & 3 & 5 & $\mathbf{0}$ \\
\hline \multirow[t]{9}{*}{ Santa Clara. . } & Mountain View... & April 10 & 5 & 4 & 5 & 0 \\
\hline & & April 15 & 5 & 5 & 5 & 0 \\
\hline & Milpitas..... & $\{$ April 8 & 10 & 8 & 10 & 0 \\
\hline & & Sept. 17 & 5 & 4 & 5 & $\mathbf{0}$ \\
\hline & Baudin...$\ldots \ldots$. & Dec. 20 & 10 & 8 & 10 & $\mathbf{0}$ \\
\hline & Blue Hall........ & Dec. 20 & 10 & 7 & 10 & $\mathbf{0}$ \\
\hline & Compton.......... & June 25 & 15 & 11 & 15 & $\mathbf{0}$ \\
\hline & Gardena......... & $\{$ Nov. 13 & 30 & 24 & 30 & 0 \\
\hline & & June 25 & 10 & 3 & 10 & 0 \\
\hline \multirow[t]{8}{*}{ Los Angeles. } & Hawthorne....... & Dec. 6 & 5 & 2 & 5 & 0 \\
\hline & Lomita........... & June 25 & 15 & 5 & 15 & $\mathbf{0}$ \\
\hline & Malibu Beach.... & Dec. 8 & 10 & 5 & 10 & 0 \\
\hline & Moneta........... & Dec. 6 & 5 & 2 & 5 & 0 \\
\hline & San Fernando.... & Dec. 20 & 15 & 9 & 5 & 0 \\
\hline & Sawtelle.......... & Dec. 6 & 10 & 3 & 10 & $\mathbf{0}$ \\
\hline & Venice............ & June 25 & 5 & 4 & 5 & 0 \\
\hline & Santa Ana... & $\{$ Dec. 7 & 10 & 6 & 10 & 0 \\
\hline \multirow[t]{3}{*}{ Orange.............. } & & June 28 & 20 & 1 & 15 & 0 \\
\hline & Seal Beach....... & Dec. 7 & 10 & 4 & 10 & $\mathbf{0}$ \\
\hline & Wintersburg....... & Dec. 7 & 10 & 6 & 10 & $\mathbf{0}$ \\
\hline \multirow[t]{2}{*}{ San Diego.......... } & Chula Vista.. & $\{$ June 30 & 10 & 1 & 5 & 0 \\
\hline & & Dec. 5 & 15 & 3 & 15 & 0 \\
\hline Total........... & & ………… & 275 & 148 & 255 & 0 \\
\hline Percentage...... & & $\ldots \ldots \ldots \ldots$ & $\cdots \cdots$ & 65.8 & $\cdots \cdots$ & 0.0 \\
\hline
\end{tabular}




\section{PROPERTY STUDIES OF VIRUS}

Filterability.-Filtration experiments were conducted by C. G. Weigle. The centrifuged extract from the leaves of celery naturally infected with western celery mosaic was filtered through Chamberland porcelain filters. One hour was allowed for the filtration at a negative pressure of 15-20 milligrams of mercury at room temperature. Six grades of Chamberland filters were used. The filtrates and unfiltered controls were inoculated in healthy celery. The results are shown in table 5 . Western-

TABLE 5

Filtration of Western-Celery-Mosaic Virus through Chamberland PorCElatn Filters

\begin{tabular}{|c|c|c|c|c|c|c|c|c|c|c|}
\hline \multirow{2}{*}{$\begin{array}{c}\text { Filter } \\
\text { No. }\end{array}$} & \multicolumn{2}{|c|}{ Experiment No. 1} & \multicolumn{2}{|c|}{ Experiment No. 2} & \multicolumn{2}{|c|}{ Experiment No. 3} & \multicolumn{2}{|c|}{ Experiment No. 4} & \multicolumn{2}{|c|}{ Total } \\
\hline & $\begin{array}{l}\text { Plants } \\
\text { inoc- } \\
\text { ulated }\end{array}$ & $\underset{\text { infected }}{\text { Plants }}$ & $\begin{array}{l}\text { Plants } \\
\text { inoc- } \\
\text { ulated }\end{array}$ & $\begin{array}{c}\text { Plants } \\
\text { infected }\end{array}$ & $\begin{array}{l}\text { Plants } \\
\text { inoc- } \\
\text { ulated }\end{array}$ & $\underset{\text { infected }}{\text { Plants }}$ & $\begin{array}{c}\text { Plants } \\
\text { inoc- } \\
\text { ulated }\end{array}$ & $\begin{array}{l}\text { Plants } \\
\text { infected }\end{array}$ & $\begin{array}{l}\text { Plants } \\
\text { inoc- } \\
\text { ulated }\end{array}$ & $\begin{array}{l}\text { Plants } \\
\text { infected }\end{array}$ \\
\hline L3 & 5 & 3 & 5 & 2 & 5 & 3 & 3 & 0 & 18 & 8 \\
\hline L5 & 5 & 1 & 5 & 3 & 5 & 2 & 3 & 0 & 18 & 6 \\
\hline L7 & 5 & 2 & 5 & 0 & 5 & 2 & 3 & 0 & 18 & 4 \\
\hline L9 & 5 & 0 & 5 & 1 & .. & . & & $\cdots$ & 10 & 1 \\
\hline L11 & $\mathbf{5}$ & 2 & 5 & 1 & 5 & 1 & 3 & 0 & 18 & 4 \\
\hline L13 & 5 & 1 & 5 & 0 & 5 & 1 & 3 & 0 & 18 & 2 \\
\hline $\begin{array}{l}\text { Unfil- } \\
\text { tered } \\
\text { control }\end{array}$ & & & & & & & & & & \\
\hline control & 5 & 3 & 5 & 2 & $\ldots$ & .. & 6 & 2 & 16 & 7 \\
\hline
\end{tabular}

celery-mosaic virus passed through all grades of Chamberland filters (L3, L5, L7, L9, L11, L13).

Thermal Inactivation.- - The thermal inactivation of the western-celery-mosaic virus was determined in extracted juice from the leaves of naturally infected celery. Ten ce of diseased juice was poured into thin glass test tubes, which were then plugged with cotton and submerged in a water bath maintained at the desired temperature by an electric thermostat. The water was kept in circulation by an agitator connected to an electric motor. The time of exposure in the water bath was 11 minutes. About 1 minute was required for the heat to penetrate the glass test tube and bring the temperature of the extract to that of the constant-temperature water bath. After the exposure to the required temperature, the test tubes were cooled rapidly in running tap water. Unheated controls were used in each test. Determinations were made only at $5^{\circ} \mathrm{C}$ intervals. Table 6 shows that the diseased celery juice remained infective after heating at $55^{\circ} \mathrm{C}$ for 10 minutes, but the virus was inactivated at $60^{\circ}$. 
Effect of Freezing Virus Extract.-The juice from the leaves of naturally infected celery was placed in cold storage at $-18^{\circ} \mathrm{C}$ immediately after extraction. The number of infections obtained during a period of 18 months is shown in table 7. Freezing the extracted juice from diseased

TABLE 6

Thermal Inactivation of Western-Celery-Mosaic Virus

\begin{tabular}{|c|c|c|c|c|c|}
\hline \multirow{2}{*}{ Temperature, ${ }^{\circ} \mathrm{C}$} & \multicolumn{2}{|c|}{$\begin{array}{l}\text { Preparations tested and } \\
\text { found infectious }\end{array}$} & \multicolumn{3}{|c|}{$\begin{array}{l}\text { Celery plants inoculated } \\
\text { and infected }\end{array}$} \\
\hline & $\begin{array}{l}\text { Number } \\
\text { tested }\end{array}$ & $\begin{array}{l}\text { Number } \\
\text { infectious }\end{array}$ & $\begin{array}{l}\text { Number } \\
\text { inoculated }\end{array}$ & $\begin{array}{l}\text { Number } \\
\text { infected }\end{array}$ & $\begin{array}{l}\text { Per cent } \\
\text { infected }\end{array}$ \\
\hline Unheated .................. & 24 & 24 & 120 & 94 & 78.3 \\
\hline $35 \ldots \ldots \ldots \ldots \ldots \ldots \ldots \ldots$ & 4 & 4 & 20 & 18 & 90.0 \\
\hline $40 \ldots \ldots \ldots \ldots \ldots \ldots \ldots \ldots$ & 4 & 4 & 20 & 16 & 80.0 \\
\hline $45 \ldots \ldots$ & 9 & 9 & 45 & 33 & 73.3 \\
\hline $50 \ldots$ & 9 & 5 & 45 & 5 & 11.1 \\
\hline $55 \ldots$ & 24 & 3 & 120 & 9 & 7.5 \\
\hline $60 \ldots$ & 24 & 0 & 120 & 0 & 0.0 \\
\hline $70 \ldots$ & 9 & 0 & 45 & 0 & 0.0 \\
\hline
\end{tabular}

celery did not inactivate the virus of western celery mosaic at the end of 18 months.

Tolerance to Dilution.-The tolerance to dilution of the western-celery-mosaic virus was determined with the expressed juice from the leaves of naturally infected celery. The diluent consisted of sterile distilled

TABLE 7

Inoculations of Healthy Celery With Western-Celery-Mosaic JUICE KePt IN COLd STORAGe AT $-18^{\circ} \mathrm{C}$

\begin{tabular}{c|c||c|c}
\hline $\begin{array}{c}\text { Age of virus extract, } \\
\text { months }\end{array}$ & $\begin{array}{c}\text { Plants infected } \\
\text { (of 5 inoculated) }\end{array}$ & $\begin{array}{c}\text { Age of virus extract, } \\
\text { months }\end{array}$ & $\begin{array}{c}\text { Plants infected } \\
\text { (of 5 inoculated) }\end{array}$ \\
\hline $1 / 2$ & 5 & 5 & 3 \\
1 & 5 & 6 & 2 \\
2 & 4 & 12 & 4 \\
3 & 5 & 18 & 2 \\
4 & 4 &. &. \\
\hline
\end{tabular}

water. The diluted juice was thoroughly agitated by pouring the solution back and forth in two beakers.

The results are shown in table 8 . Western-celery-mosaic virus extracts showed a great variation in tolerance to dilution. The maximum tolerance of the virus to dilution demonstrated in extracted diseased celery juice was $1: 4,000$. With some of the preparations, infections were pro- 
duced at a dilution of $1: 10$ or $1: 50$ but not at higher dilutions ; this indicates a low concentration of virus.

Tolerance to Aging in Vitro.-Tests were made to determine the longevity of the virus in diseased celery juice when exposed to the air at

TABLE 8

Tolerance to Dilution of Western-Celery-Mosaic Virus

\begin{tabular}{|c|c|c|c|c|c|c|c|}
\hline \multirow{2}{*}{ Dilution } & \multirow{2}{*}{$\begin{array}{c}\text { Number of } \\
\text { prepara- } \\
\text { tions } \\
\text { infectious } \\
\text { (of } 12 \text { tested) }\end{array}$} & \multicolumn{2}{|c|}{$\begin{array}{l}\text { Plants infected } \\
\text { (of } 60 \text { inoculated) }\end{array}$} & \multirow{2}{*}{ Dilution } & \multirow{2}{*}{$\begin{array}{c}\text { Number of } \\
\text { prepara- } \\
\text { tions } \\
\text { infectious } \\
\text { (of } 12 \text { tested) }\end{array}$} & \multicolumn{2}{|c|}{$\begin{array}{l}\text { Plants infected } \\
\text { (of } 60 \text { inoculated) }\end{array}$} \\
\hline & & Number & Per cent & & & Number & Per cent \\
\hline ControlNo.1* & 12 & 40 & 66.7 & ControlNo.2* & 12 & 59 & 98.3 \\
\hline $1: 10 \ldots \ldots \ldots$ & 11 & 28 & 46.7 & $1: 1,500 \ldots \ldots$ & 5 & 6 & 10.0 \\
\hline $1: 50 \ldots$ & 11 & 22 & 36.7 & 1:2,000. & 0 & 0 & 0.0 \\
\hline 1:100. & 8 & 16 & 26.7 & $1: 2,500$. & 3 & 4 & 6.7 \\
\hline $1: 500 .$. & 4 & 4 & 6.7 & $1: 3,000$ & 4 & 6 & 10.0 \\
\hline $1: 700 \ldots$ & 4 & 5 & $8.3^{\circ}$ & $1: 4,000$ & 1 & 1 & 1.7 \\
\hline $1: 1,000 \ldots$ & 3 & 3 & 5.0 & $1: 5,000 \ldots \ldots$ & 0 & 0 & 0.0 \\
\hline
\end{tabular}

* Control No. 1 and dilutions from 1:10 to 1:1,000 were tested with one set of preparations; and control No. 2 with dilutions $1: 1,500$ to $1: 5,000$ with another set.

room temperatures. Ten ce of the expressed juice from the leaves of naturally infected celery was poured into sterile test tubes plugged with cotton. Daily inoculations of the extract stored in vitro were made for a period of 10 days.

The infections obtained are indicated in table 9. There is evidently

TABLE 9

Tolerance to Aging in Vitro of Western-Celery-Mosaic Virus

\begin{tabular}{|c|c|c|c|c|c|c|c|}
\hline \multirow{2}{*}{$\begin{array}{l}\text { Days } \\
\text { exposed }\end{array}$} & \multirow{2}{*}{$\begin{array}{c}\text { Number of } \\
\text { prepara- } \\
\text { tions } \\
\text { infectious } \\
\text { (of } 10 \text { tested) }\end{array}$} & \multicolumn{2}{|c|}{$\begin{array}{l}\text { Plants infected } \\
\text { (of } 50 \text { inoculated) }\end{array}$} & \multirow{2}{*}{$\begin{array}{l}\text { Days } \\
\text { exposed }\end{array}$} & \multirow{2}{*}{$\begin{array}{c}\text { Number of } \\
\text { prepara- } \\
\text { tions } \\
\text { infectious } \\
\text { (of } 10 \text { tested) }\end{array}$} & \multicolumn{2}{|c|}{$\begin{array}{l}\text { Plants infected } \\
\text { (of } 50 \text { inoculated) }\end{array}$} \\
\hline & & Number & Per cent & & & Number & Per cent \\
\hline 0 (control)... & 10 & 44 & 88.0 & $6 \ldots \ldots \ldots$ & 1 & 2 & 4.0 \\
\hline $1 \ldots \ldots \ldots$ & 10 & 42 & 84.0 & $7 \ldots \ldots$ & 0 & 0 & 0.0 \\
\hline $2 \ldots$ & 10 & 31 & 62.0 & 8. & 0 & 0 & 0.0 \\
\hline 3. & 7 & 18 & 36.0 & 9. & 0 & 0 & 0.0 \\
\hline 4. . & 5 & 10 & 20.0 & 10. & 0 & 0 & 0.0 \\
\hline 5... & 3 & 5 & 10.0 & & . & . & $\ldots$ \\
\hline
\end{tabular}

considerable reduction of infectivity of the virus after the extract was stored in vitro at room temperature for a period of 4 to 6 days, and no infections were obtained at the end of 7 days.

Resistance to Alcohol Treatment.-In testing the effect of treatment with alcohol on diseased celery juice, small quantities of centrifuged juice were brought to various percentages of alcohol by the addition of 
absolute alcohol, and the mixture was allowed to stand for a period of 1 hour. A precipitate was formed, which was separated from the supernatant liquid by centrifuging for 15 minutes at 3,500 revolutions per minute. The supernatant alcoholic solution was poured from the tubes. The precipitate was washed with several changes of sterile distilled water and then resuspended in distilled water equal to the original volume of the extracted celery juice.

The results of inoculating healthy celery plants with the supernatant liquid and the precipitate resuspended in distilled water are shown in table 10. The western-celery-mosaic virus in the supernatant liquid was

TABLE 10

Resistance of Western-Celert-Mosaic Virus Extract to Alcohol during ONE-HOUR EXPOSURES

\begin{tabular}{|c|c|c|c|c|c|c|}
\hline \multirow{3}{*}{$\begin{array}{l}\text { Per cent } \\
\text { alcohol }\end{array}$} & \multirow{2}{*}{\multicolumn{2}{|c|}{$\begin{array}{l}\text { Number of preparations } \\
\text { infectious (of } 5 \text { tested) }\end{array}$}} & \multicolumn{4}{|c|}{ Plants infected (of 25 inoculated) } \\
\hline & & & \multicolumn{2}{|c|}{ Number } & \multicolumn{2}{|c|}{ Per cent } \\
\hline & $\begin{array}{l}\text { Supernatant } \\
\text { liquid }\end{array}$ & Precipitate & $\begin{array}{c}\text { Supernatant } \\
\text { liquid }\end{array}$ & Precipitate & $\underset{\text { Siquid }}{\text { Supernatant }}$ & Precipitate \\
\hline 0 (control)... & 5 & 5 & 21 & 25 & 84.0 & 100.0 \\
\hline & 4 & 5 & 15 & 25 & 60.0 & 100.0 \\
\hline 20. & 4 & 5 & 6 & 25 & 24.0 & 100.0 \\
\hline $30 \ldots \ldots \ldots$ & 3 & 5 & 4 & 19 & 16.0 & 76.0 \\
\hline $40 \ldots \ldots \ldots$ & 0 & 1 & 0 & 1 & 0.0 & 4.0 \\
\hline $50 \ldots \ldots \ldots$ & 0 & 0 & 0 & 0 & 0.0 & 0.0 \\
\hline
\end{tabular}

capable of withstanding treatment with 30 per cent alcohol, and the precipitate, treatment with 40 per cent alcohol for 1 hour. The resistance of the virus to alcohol in the supernatant and in the precipitate were probably equal. Most of the virus was apparently contained in the alcohol precipitate, and consequently a higher percentage of infections resulted from inoculations made from the precipitate.

\section{INSECTS WHICH FAILED TO TRANSMIT VIRUS}

High populations of beetles, plant bugs, and leafhoppers sometimes occur in celery fields, and tests were made to determine whether these insects could transmit the virus of western celery mosaic. The western twelve-spotted cucumber beetle (Diabrotica soror Lec.) and the tarnished plant bug (Lygus pratensis [Linn.]) were transferred frequently from diseased to healthy celery, back to diseased, and again to healthy celery plants but without results. Similar methods were used with several species of leafhoppers, using from 10 to 25 adults in each test, but all 
attempts to transmit the virus were failures. Table 11 indicates the number of tests made with each species of insect : no infections were obtained with any of these insects.

Some of the leafhoppers are vectors of other virus diseases of celery. The aster leafhopper (Macrosteles divisus [Uhl.]) (28), the geminate leafhopper (Thamnotettix geminatus Van D.) (30), and the mountain leafhopper (Thamnotettix montanus Van D.) (30) have been reported as transmitting the virus of celery yellows, which is identical with Cali-

TABLE 11

Insects that Failed to Transmit Western-Celery-Mosaic Virus

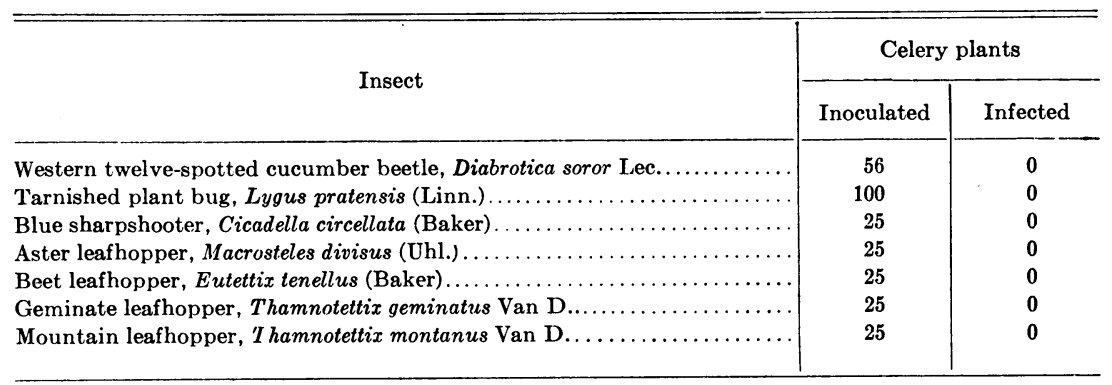

fornia aster yellows. Celery has been experimentally infected with sugarbeet curly top by the beet leafhopper, Eutettix tenellus (Baker) (28).

\section{APHID TRANSMISSION OF VIRUS}

Vectors Which Do Not Breed on Celery.-It was demonstrated that aphids which have not been found to breed on celery under natural conditions were capable of transmitting the virus of western celery mosaic. The mealy plum aphid (Hyalopterus pruni [Geoff.]) was transferred from the leaves of prune trees, the rose aphid (Macrosiphum rosae [Linn.]) from rose bushes, the black cherry aphid (Myzus cerasi [Fabr.]) from the leaves of cherry trees, to western-celery-mosaic plants for 1 day; and the next day 20 aphids were transferred to each healthy celery plant. In the case of the cabbage aphid (Brevicoryne brassicae [Linn.]), pea aphid (Macrosiphum pisi [Kalt.]), and the false cabbage or turnip aphid (Lipaphis pseudobrassicae [Davis]), previously noninfective aphids were used in the transmission of the virus. All species of aphids died on celery within a few days.

The results obtained are indicated in table 12. An examination of this table shows that the highest percentage of transmission of the westerncelery-mosaic virus was by the cabbage aphid and the lowest by the mealy 
plum and rose aphids. No determinations of different species of winged aphids in celery fields have been made, but large populations of winged aphids have been collected in the celery fields after the pasture vegetation on the foothills and the weeds in the cultivated areas had become dry. The influx of different species of winged aphids into celery fields, even if these are not able to breed on celery, probably plays an important rôle in the dissemination of the western-celery-mosaic virus.

Vectors Breeding on Celery.-Field investigations were conducted to

TABLE 12

Transmission of Western Celery Mosaic by Aphids That Do Not Breed on Celery Under Natural Conditions

\begin{tabular}{|c|c|c|c|}
\hline \multirow{2}{*}{ Aphid } & \multicolumn{2}{|c|}{ Celery plants } & \multirow{2}{*}{$\begin{array}{l}\text { Per cent } \\
\text { infected }\end{array}$} \\
\hline & Inoculated & Infected & \\
\hline Cabbage aphid, Brevicoryne brassicae, Linn............. & 35 & 27 & 77.1 \\
\hline Mealy plum aphid, Hyalopterus pruni (Geoff.).. & 75 & 7 & 9.3 \\
\hline Pea aphid, Macrosiphum pisi (Kalt.).......... & 35 & 13 & 37.1 \\
\hline Rose aphid, Macrosiphum rosae (Linn.).. & 75 & 9 & 12.0 \\
\hline Black cherry aphid, Myzus cerasi (Fabr.)... & 35 & 15 & 42.9 \\
\hline $\begin{array}{l}\text { False cabbage or turnip aphid, Lipaphis pseudobrassicae } \\
\quad \text { (Davis) } \ldots \ldots \ldots \ldots \ldots \ldots \ldots \ldots \ldots\end{array}$ & 35 & 16 & 45.7 \\
\hline
\end{tabular}

determine the aphids which breed on celery under natural conditions in California. The following species of aphids were reared on celery :

Celery leaf aphid, Aphis apigraveolens Essig (see Essig (7), fig. 1)

Celery aphid, Aphis apii Theobald (see Essig (7), fig. 2)

Rusty-banded aphid, Aphis ferruginea-striata Essig (see Essig (7), fig. 3)

Cotton or melon aphid, Aphris gossypii Glover (see Essig (7), fig. 4)

Erigeron root aphid, Aphis middletonii Thomas (see Essig (7), fig. 6)

Bean or dock aphid, Aphis rumicis Linnaeus

Yellow willow aphid, Cavariella capreae (Fabricius) (see Essig (7), fig. 7)

Lily aphid, Myzus circumflexus (Buckton) (see Essig (7), fig. 8)

Foxglove aphid, Myzus convolvuli (Kaltenbach) (see Essig (7), fig. 9)

Green peach aphid, Myzus persicae (Sulzer) (see Essig (7), fig. 11)

Honeysuckle aphid, Rhopalosiphum melliferum (Hottes) (see Essig (7), fig. 12)

The lily aphid has been taken on celery kept out of doors at Berkeley but has not been collected in celery fields up to the present time.

The rusty-banded aphid has been found feeding occasionally on the roots of celery, or on the base (stem) of the plant below the surface of the soil, but more often occurs between the petioles near the base of the plant and when abundant covers the petioles and veins of the leaves.

In the preceding paper, Essig (7) reports that the erigeron root aphid feeds on the roots of asters and on a wide range of other plants in Cali- 
fornia. It has been found on the roots of celery near Chula Vista, San Diego County, and in the Santa Clara Valley.

Some species of aphids become abundant in celery fields during certain seasons of the year. The cotton or melon aphid was abundant on celery in the Santa Clara Valley on July 8, 1935; but this aphid when reared on celery in the greenhouse becomes greatly reduced in size and the populations are slow to develop. The green peach aphid was numerous on celery in the Santa Clara Valley on December 19, 1935, and yet this aphid was difficult to rear on celery in the greenhouse. An enormous number of host plants of some of these aphids is discussed by Essig (7) in the preceding paper, and in all probability the abundance of some species of aphids on celery during certain seasons of the year hinges on the drying of some of their breeding plants.

Transmission of Virus by Different Species of Aphids.-Celery infected with western celery mosaic was shipped by plant pathologists, county agents, and growers and was collected by the writers from many celery districts in California to determine the distribution and relative importance of different species of aphids and whether a specific vector was transmitting the virus.

The diseased plants were transplanted in pots enclosed in cages and the aphids were allowed to multiply on the plants. High populations of aphids were used in each test, but no accurate count of the number of aphids was made; the leaves with the aphids were cut from the diseased plant and dropped on the leaves or between the petioles of the healthy plants.

Table 13 gives the number of infections obtained with the different species of aphids. An examination of the average percentages of celery plants infected by different species of aphids in this table shows that the bean or dock aphid and the yellow willow aphid were not efficient vectors of the virus.

Attempts to Transmit Virus to Cucumber Plants by Means of Aphids.The results of mechanical inoculation of healthy celery and cucumber plants with the extract from celery infected with western celery mosaic collected in many celery districts in California are given in table 4 (p.514) and have been discussed under the heading of inoculation experiments. Attempts were made to transmit the virus from naturally infected celery with 11 species of aphids to healthy celery and the cucumber plants. Celery plants showing leaf abnormalities, such as club-shaped leaves (fig. 5, p. 506), linear leaflets (plate $6, A, B, E, F$ ) or blisterlike pustules on the leaflets (plate $6, D$ ), were also tested. Previously noninfective aphids reared on celery naturally infected with western celery mosaic and on 
TABLE 13

Transmission of Western-Celert-Mosaic Virus by Difrerent Spectes of APHIDS FROM Diseased to Healthy Celery

\begin{tabular}{c|c|c|c|c}
\hline \multicolumn{2}{c|}{ Source of virus } & $\begin{array}{c}\text { Dates aphids } \\
\text { inoculated plants }\end{array}$ & $\begin{array}{c}\text { Plants } \\
\text { inoculated }\end{array}$ & $\begin{array}{c}\text { Plants } \\
\text { infected }\end{array}$ \\
\hline County & District & \\
\hline
\end{tabular}

Celery leaf aphid, Aphis apigraveolens Essig

\begin{tabular}{|c|c|c|c|c|}
\hline & (San Fernando. & Feb 3-6 & 5 & 5 \\
\hline \multirow[t]{2}{*}{ Los Angeles............ } & $\{$ Long Beach . . . . . . . . & Feb. 5-8.... & 5 & 5 \\
\hline & Sawtelle............. & Feb. $5-8 \ldots \ldots \ldots \ldots \ldots$ & 5 & 5 \\
\hline Orange............... & 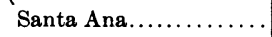 & Feb. $5-8 \ldots \ldots \ldots \ldots \ldots$ & 5 & 4 \\
\hline Sacramento ............ & Sacramento Pocket..... & Mar. 2-5............ & 5 & 3 \\
\hline Total. . & & & 25 & 22 \\
\hline Percentage............. & $\ldots \ldots \ldots \ldots \ldots \ldots \ldots \ldots$ & $\ldots \ldots \ldots \ldots \ldots \ldots \ldots \ldots$ & $\ldots$ & 88.0 \\
\hline
\end{tabular}

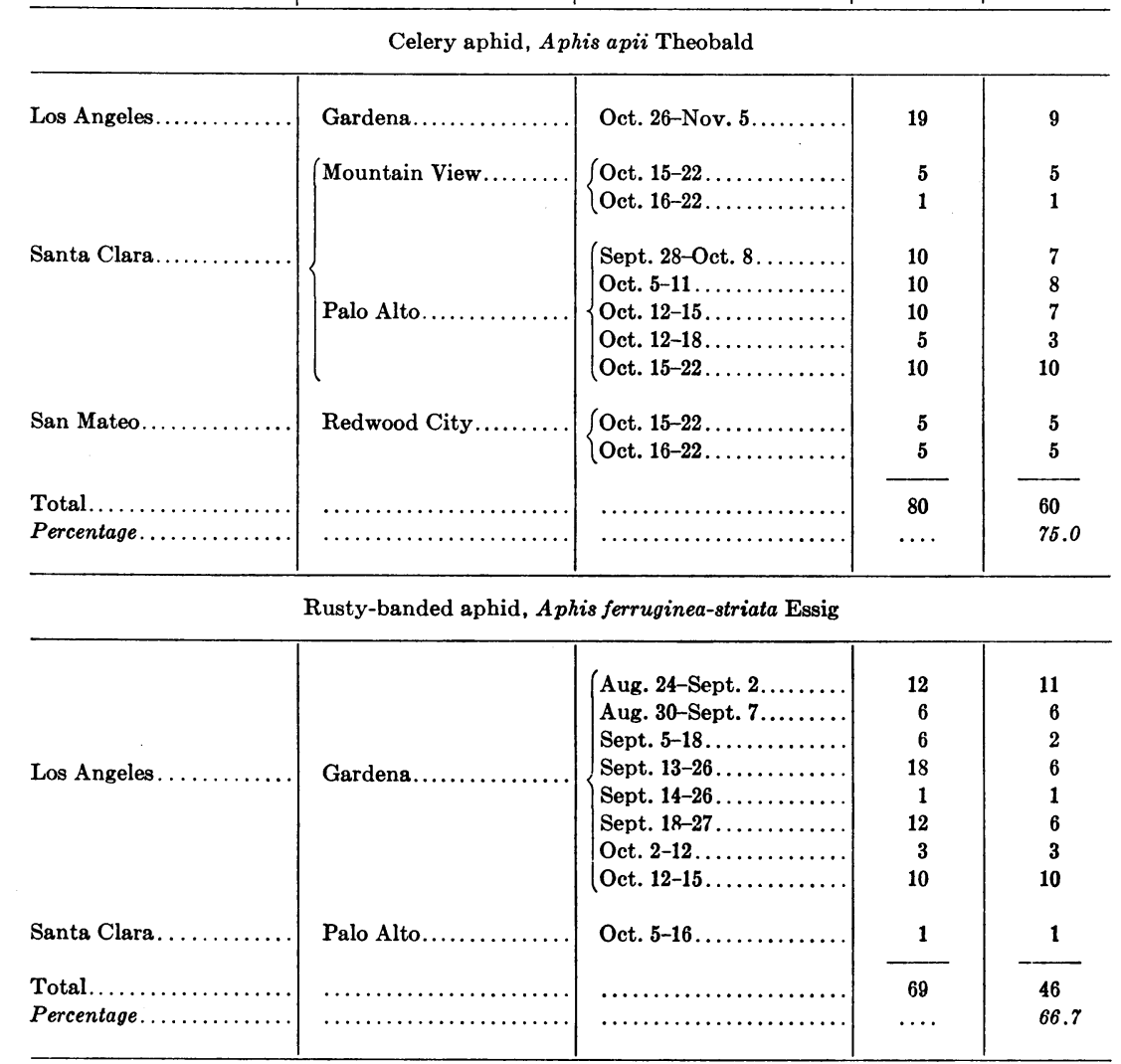


TABLE 13-(Continued)

\begin{tabular}{c|c|c|c|c}
\hline \multicolumn{2}{c|}{ Source of virus } & $\begin{array}{c}\text { Dates aphids } \\
\text { inoculated plants }\end{array}$ & $\begin{array}{c}\text { Plants } \\
\text { inoculated }\end{array}$ & $\begin{array}{c}\text { Plants } \\
\text { infected }\end{array}$ \\
\hline County & District &
\end{tabular}

Cotton or melon aphid, Aphis gossypii Glover

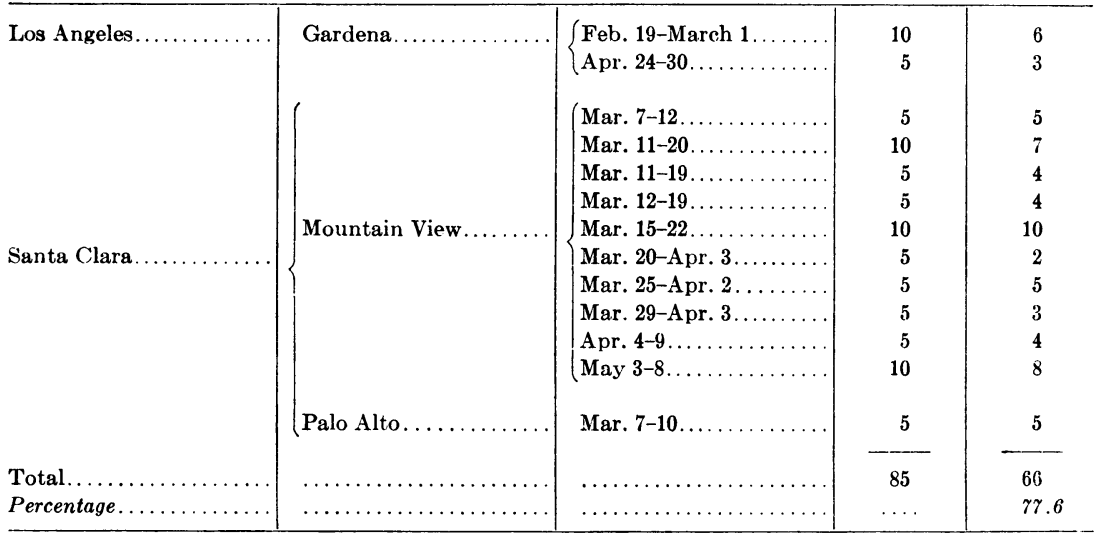

Erigeron root aphid, Aphis middletonii Thomas

\begin{tabular}{|c|c|c|c|c|}
\hline Santa Clara ............. & Milpitas ............. & $\left\{\begin{array}{l}\text { Aug. } 5-8 \ldots \ldots \ldots \ldots \ldots \ldots \\
\text { Aug. } 17-20 \ldots \ldots \ldots \ldots \ldots \\
\text { Aug. } 19-22 \ldots \ldots \ldots \ldots \ldots \\
\text { Aug. } 22-26 \ldots \ldots \ldots \ldots \ldots \\
\text { Aug. } 23-26 \ldots \ldots \ldots \ldots \ldots\end{array}\right.$ & $\begin{array}{r}12 \\
4 \\
16 \\
5 \\
10\end{array}$ & $\begin{array}{r}11 \\
3 \\
14 \\
4 \\
10\end{array}$ \\
\hline 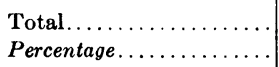 & $\begin{array}{l}\ldots \ldots \ldots \ldots \ldots \ldots \ldots \ldots \\
\ldots \ldots \ldots \ldots \ldots \ldots \ldots\end{array}$ & $\begin{array}{l}\ldots \ldots \ldots \ldots \ldots \ldots \ldots \ldots \\
\ldots \ldots \ldots \ldots \ldots \ldots \ldots \ldots \ldots\end{array}$ & $\begin{array}{c}47 \\
\ldots\end{array}$ & $\begin{array}{l}42 \\
89.4\end{array}$ \\
\hline
\end{tabular}

Bean or dock aphid, Aphis rumicis Linn.

\begin{tabular}{|c|c|c|c|c|}
\hline Santa Clara............ & $($ Milpitas.............. & $\left\{\begin{array}{l}\text { May } 1-7 \ldots \ldots \ldots \ldots \ldots \\
\text { May } 5-9 \ldots \ldots \ldots \ldots \ldots\end{array}\right.$ & $\begin{array}{l}10 \\
25\end{array}$ & $\begin{array}{l}1 \\
7\end{array}$ \\
\hline & (Palo Alto............. & Sept. 17-Oct. 3 . & 10 & 1 \\
\hline Total. & $\ldots$ & . & 45 & 9 \\
\hline Percentage............. & $\ldots \ldots \ldots \ldots \ldots \ldots \ldots$ & $\ldots \ldots \ldots \ldots \ldots \ldots$ & $\ldots$ & 20.0 \\
\hline
\end{tabular}

Yellow willow aphid, Cavariella capreae (Fabr.)

Los Angeles.

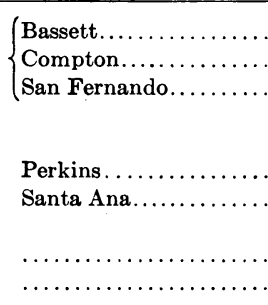

\begin{tabular}{|c|c|c|}
\hline Jan. 8-11. & 5 & 4 \\
\hline Jan. $9-13 \ldots \ldots \ldots \ldots$ & 5 & 1 \\
\hline$(J a n .9-13 \ldots \ldots \ldots \ldots$ & 5 & 1 \\
\hline Mar. 9-12........... & 5 & 2 \\
\hline Mar. $9-12 \ldots \ldots \ldots \ldots \ldots$ & 5 & 2 \\
\hline Mar. $9-12 \ldots \ldots \ldots \ldots \ldots$ & 5 & 1 \\
\hline . & 30 & 11 \\
\hline 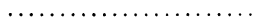 & .. & 36.7 \\
\hline
\end{tabular}


TABLE 13-(Concluded)

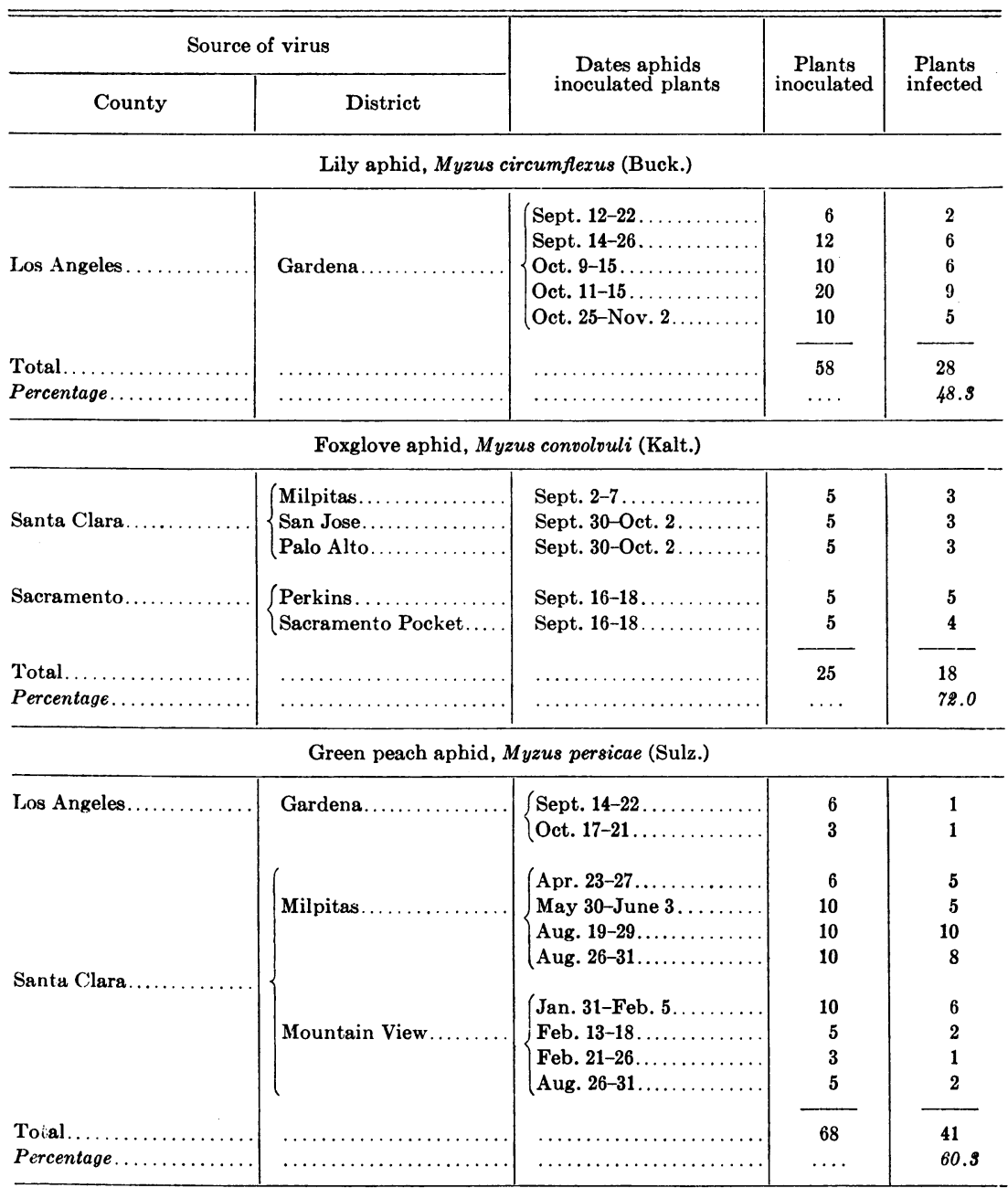

Honeysuckle aphid, Rhopalosiphum melliferum (Hottes)

\begin{tabular}{|c|c|c|c|c|}
\hline \multirow[t]{4}{*}{ Los Angeles............ } & Gardena.............. & Nov. $7-16 \ldots \ldots \ldots \ldots$ & 55 & 36 \\
\hline & (Milpitas..... & Aug. $12-15 \ldots \ldots \ldots \ldots \ldots$ & 10 & 10 \\
\hline & & (June $7-14 \ldots \ldots \ldots$. & 12 & 11 \\
\hline & Mountain View.... & $\{$ July $6-10 \ldots \ldots \ldots \ldots$ & 10 & 10 \\
\hline \multirow{3}{*}{ Santa Clara ............ } & & Oct. $5-10 \ldots \ldots \ldots \ldots$ & 2 & 2 \\
\hline & & Oct. $26-30 \ldots \ldots \ldots \ldots$ & 5 & 4 \\
\hline & Palo Alto............. & June $19-25 \ldots \ldots \ldots \ldots$ & 10 & 0 \\
\hline Total $\ldots \ldots \ldots \ldots \ldots$ & & $\ldots$ & 104 & 73 \\
\hline Percentage.............. & $\ldots \ldots \ldots \ldots \ldots \ldots \ldots$ & $\ldots \ldots \ldots \ldots \ldots \ldots \ldots$ & $\ldots$ & 70.2 \\
\hline
\end{tabular}


celery showing leaf abnormalities were transferred from each diseased celery to 5 healthy celery and 5 White Spine cucumber plants.

The results obtained are given in table 14. None of the 11 species of aphids transmitted the virus of western celery mosaic from any of the naturally infected celery plants to any of the healthy cucumber plants.

The rusty-banded aphid and the erigeron root aphid were the most efficient vectors of these species, the former infecting an average of 92 per cent and the latter 90 per cent of the healthy celery plants. Least efficient was the bean or dock aphid, which transmitted the virus to 1 of 5 healthy celery plants from 1 naturally infected plant.

Some of the celery plants with abnormal leaves were demonstrated to be naturally infected with western celery mosaic.

Comparison of Mechanical Inoculation with Transmission of Virus by Aphids.-Mechanical inoculation was compared with the transmission of the western-celery-mosaic virus by different species of aphids from naturally infected to healthy celery plants. After a large population of aphids were reared on the naturally infected celery plants, 20 aphids were transferred from each diseased plant to each of 5 healthy celery plants. The extract from each naturally infected plant, on which the aphids had fed, was also inoculated into 5 healthy celery plants.

A comparison of the results obtained is given in table 15 . The transmission of the virus from diseased to healthy celery by 11 species of aphids varied from 2.2 to 92.5 per cent. Nine lots of 20 bean or dock aphids infected only 1 of 45 plants, or 2.2 per cent, whereas with mechanical inoculation of expressed juice from the same naturally infected plants on which these aphids had fed, 40 of 45 celery plants, or 88.9 per cent, became infected. If the results with the bean or dock aphid are omitted, the transmission of the virus by 10 species of aphids varied from 35.0 to 92.5 per cent. The infections obtained by mechanical inoculation varied from 13.3 to 88.9 per cent, with an average of 48.2 per cent; this is somewhat lower than the average of 53.8 per cent obtained in the experiments reported in table 4.

Detailed records not included in table 15 indicate that infections were obtained, either by mechanical inoculation or aphid transmission from each of the naturally infected plants used as a source of virus ; in no case did both methods fail. As indicated in table 15, six species of aphids obtained the infection from all of the naturally infected plants on which they fed, but the bean or dock aphid obtained it from only 1 of 9 plants ; the results with other species were intermediate. Preparation of juice from 23 of the 102 plants failed to transmit the virus when mechanically inoculated. 


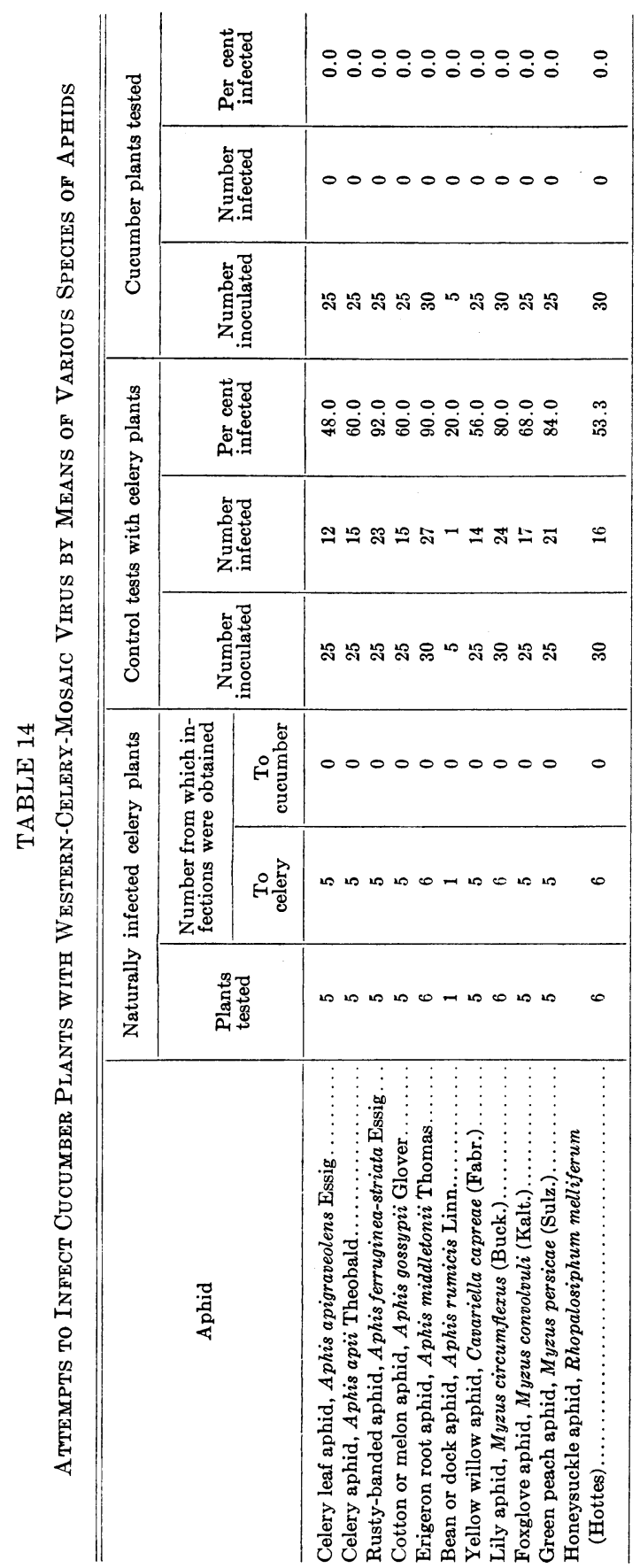




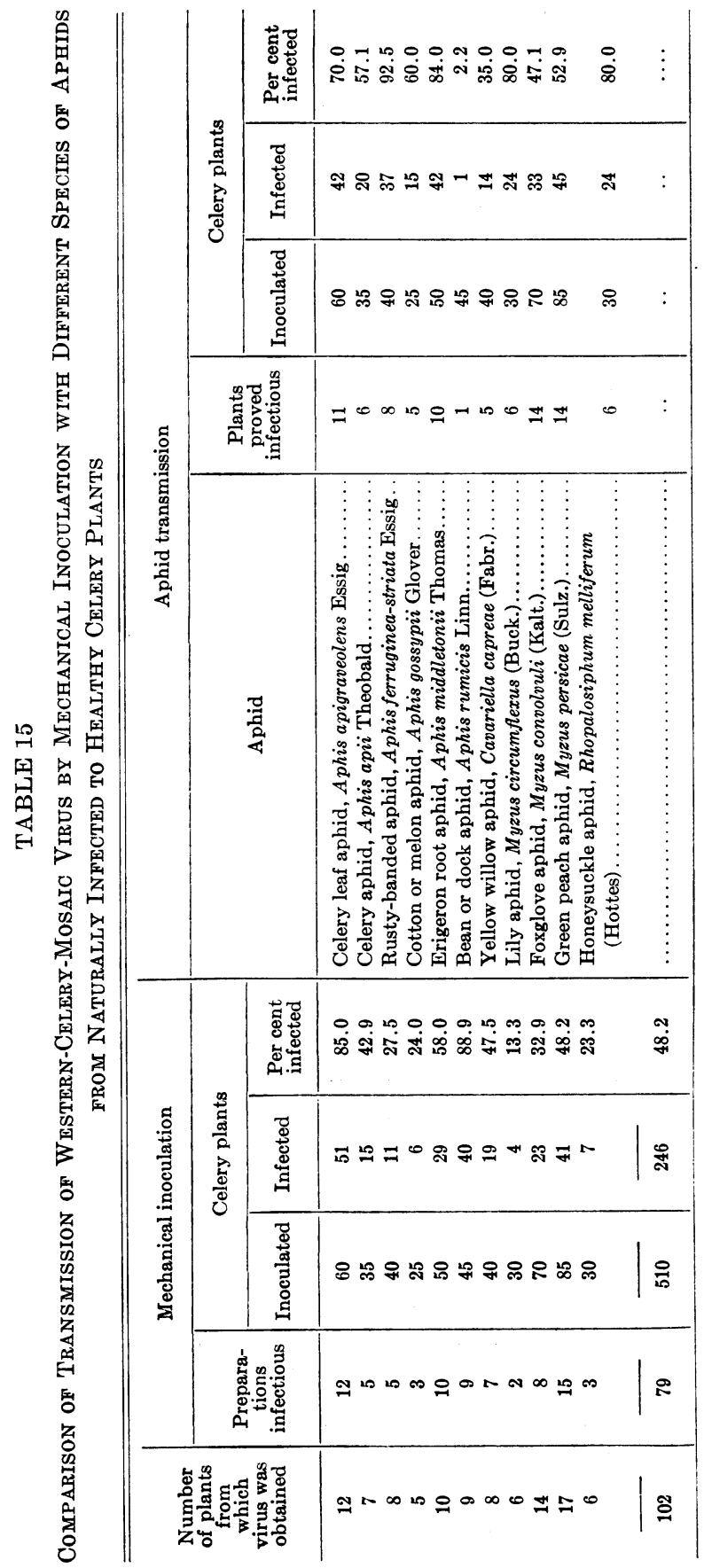


Summary of Transmission of Virus by Aphids Breeding on Celery.The average percentages of infections obtained with 11 species of aphids are summarized in table 16 . The erigeron root aphid (84.8 per cent) and the rusty-banded aphid (83.8 per cent), also a root-feeding insect, produced the largest number of infections, with the honeysuckle aphid (73.4 per cent), lily aphid (72.1 per cent), cotton or melon aphid (71.4 per cent), celery leaf aphid (64.5 per cent), green peach aphid (62.6 per cent), celery aphid (58.0 per cent), and foxglove aphid (55.9 per cent)

TABLE 16

Summary of Percentages of Infections Produced by Different SPECIES OF APHIDS

\begin{tabular}{|c|c|c|c|c|c|}
\hline Aphid & Table 13 & Table 14 & Table 15 & Table 18 & $\begin{array}{l}\text { Average } \\
\text { per- } \\
\text { centage }\end{array}$ \\
\hline Celery leaf aphid, Aphis apigraveolens Essig. & 88.0 & 48.0 & 70.0 & 52.0 & 64.5 \\
\hline Celery aphid, Aphis apii Theobald......... & 75.0 & 60.0 & 57.1 & 40.0 & 58.0 \\
\hline Rusty-banded aphid, Aphis ferruginea-striata Essig & 66.7 & 92.0 & 92.5 & 84.0 & 83.8 \\
\hline Cotton or melon aphid, Aphis gossypii Glover..... & 77.6 & 60.0 & 60.0 & 88.0 & 71.4 \\
\hline Erigeron root aphid, A phis middletonii Thomas... & 89.4 & 90.0 & 84.0 & 76.0 & 84.8 \\
\hline Bean or dock aphid, Aphis rumicis Linn.......... & 20.0 & 20.0 & 2.2 & $\ldots$ & 14.1 \\
\hline Yellow willow aphid, Cavariella capreae (Fabr.).... & 36.7 & 56.0 & 35.0 & 32.0 & 39.9 \\
\hline Lily aphid, Myzus circumflexus (Buck.)........... & 48.3 & 80.0 & 80.0 & 80.0 & 72.1 \\
\hline Foxglove aphid, Myzus convolvuli (Kalt.).......... & 72.0 & 68.0 & 47.1 & 36.7 & 55.9 \\
\hline Green peach aphid, Myzus persicae (Sulz.)........ & 60.3 & 84.0 & 52.9 & 53.3 & 62.6 \\
\hline $\begin{array}{l}\text { Honeysuckle aphid, } \text { Rhopalosiphum melliferum } \\
\text { (Hottes) } \ldots \ldots \ldots \ldots \ldots \ldots \ldots \ldots \ldots \ldots \ldots \ldots \ldots \ldots \ldots\end{array}$ & 70.2 & 53.3 & 80.0 & 90.0 & 73.4 \\
\hline
\end{tabular}

next in order. The rusty-banded aphid is the most important vector of the virus of western celery mosaic in California when distribution and abundance on celery are considered. The bean or dock aphid (8.6 per cent) and the yellow willow aphid (14.1 per cent) produced the lowest percentages of infections. It is evident from the high percentages of transmission of the virus by various species of aphids, that there is no specific aphid vector.

Transmission of Virus by Single Aphids.-A comparison was made of the transmission of the western-celery-mosaic virus by single winged and wingless mature aphids bred on diseased plants. Each aphid was fed on a healthy celery plant for a period of 1 day.

The results obtained are indicated in table 17. Considerable variation occurred in the ability of single aphids of different species to infect plants. The winged aphids, with the exception of one species, transmitted the virus to a lower percentage of plants than the wingless mature aphids. The highest percentage by single wingless mature aphids was 37.3 , produced by the rusty-banded aphid, while the winged forms of this species 
infected 2.0 per cent of the plants. The highest percentage of infection by single winged aphids was 7.0, produced by the celery leaf aphid, as compared with 14 per cent by the wingless mature aphids. The lowest percentages of infections were produced by the celery aphid, green peach aphid, and the foxglove aphid.

Retention of Virus by Aphids.-Four experiments were conducted to determine how long aphids would retain the virus. In the first of these, wingless aphids of ten species were transferred daily to successive

TABLE 17

Comparison of Transmission of Western-Celery-Mosaic Virus by Single Winged With Wingless Mature Aphids From Diseased to Healthy Celery Plants

\begin{tabular}{|c|c|c|c|c|c|c|}
\hline \multirow{2}{*}{ Aphid } & \multicolumn{3}{|c|}{$\begin{array}{l}\text { Results with winged } \\
\text { aphids }\end{array}$} & \multicolumn{3}{|c|}{$\begin{array}{l}\text { Results with wingless } \\
\text { mature aphids }\end{array}$} \\
\hline & $\begin{array}{c}\text { Plants } \\
\text { inoc- } \\
\text { ulated }\end{array}$ & $\begin{array}{c}\text { Plants } \\
\text { in- } \\
\text { fected }\end{array}$ & $\begin{array}{c}\text { Percent } \\
\text { in- } \\
\text { fected }\end{array}$ & $\begin{array}{l}\text { Plants } \\
\text { inoc- } \\
\text { ulated }\end{array}$ & $\begin{array}{l}\text { Plants } \\
\text { in- } \\
\text { fected }\end{array}$ & $\begin{array}{l}\text { Percent } \\
\text { in- } \\
\text { fected }\end{array}$ \\
\hline Celery leaf aphid, Aphis apigraveolens Essig. . & 100 & 7 & 7.0 & 100 & 14 & 14.0 \\
\hline Celery aphid, Aphis apii Theobald ............ & 100 & 0 & 0.0 & 200 & 3 & 1.5 \\
\hline Rusty-banded aphid, Aphis ferruginea-striata Essig & 100 & 2 & 2.0 & 150 & 56 & 37.3 \\
\hline Cotton or melon aphid, Aphis gossypii Glover...... & 100 & 4 & 4.0 & 100 & 8 & 8.0 \\
\hline Erigeron root aphid, Aphis middletonii Thomas... & 100 & 3 & 3.0 & 300 & 10 & 3.3 \\
\hline Yellow willow aphid, Cavariella capreae (Fabr.). . & 100 & 0 & 0.0 & 200 & 5 & 2.5 \\
\hline Lily aphid, Myzus circumflexus (Buck.).... & 0 & 0 & 0.0 & 150 & 12 & 8.0 \\
\hline Foxglove aphid, Myzus convolvuli (Kalt.).... & 100 & 1 & 1.0 & 100 & 0 & 0.0 \\
\hline Green peach aphid, Myzus persicae (Sulz.)...... & 100 & 0 & 0.0 & 150 & 1 & 0.7 \\
\hline 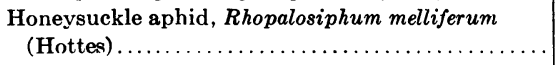 & 100 & 3 & 3.0 & 215 & 19 & 8.8 \\
\hline
\end{tabular}

healthy celery plants, 5 or 6 tests being made with each species. In each test, 20 aphids reared on diseased celery were transferred daily for 3 days to successive healthy celery plants. The aphids remained on the third celery plant for a period of one week.

The results obtained are indicated in table 18. Each of ten species of aphids transmitted the virus from diseased to healthy celery plants during the first day, but every one of the lots tested had lost the infectivity by the second day-no transmissions were obtained after the first day under greenhouse conditions. It is possible, however, that with a lowering of the temperature during the winter the aphids may retain the infectivity longer than one day under natural conditions.

In the second experiment, 20 wingless adults of the rusty-banded aphid reared on diseased celery were fed overnight on a healthy celery plant for a period of 12 hours. During the next day, the aphids were transferred hourly to 8 successive healthy celery plants. Each lot of 20 


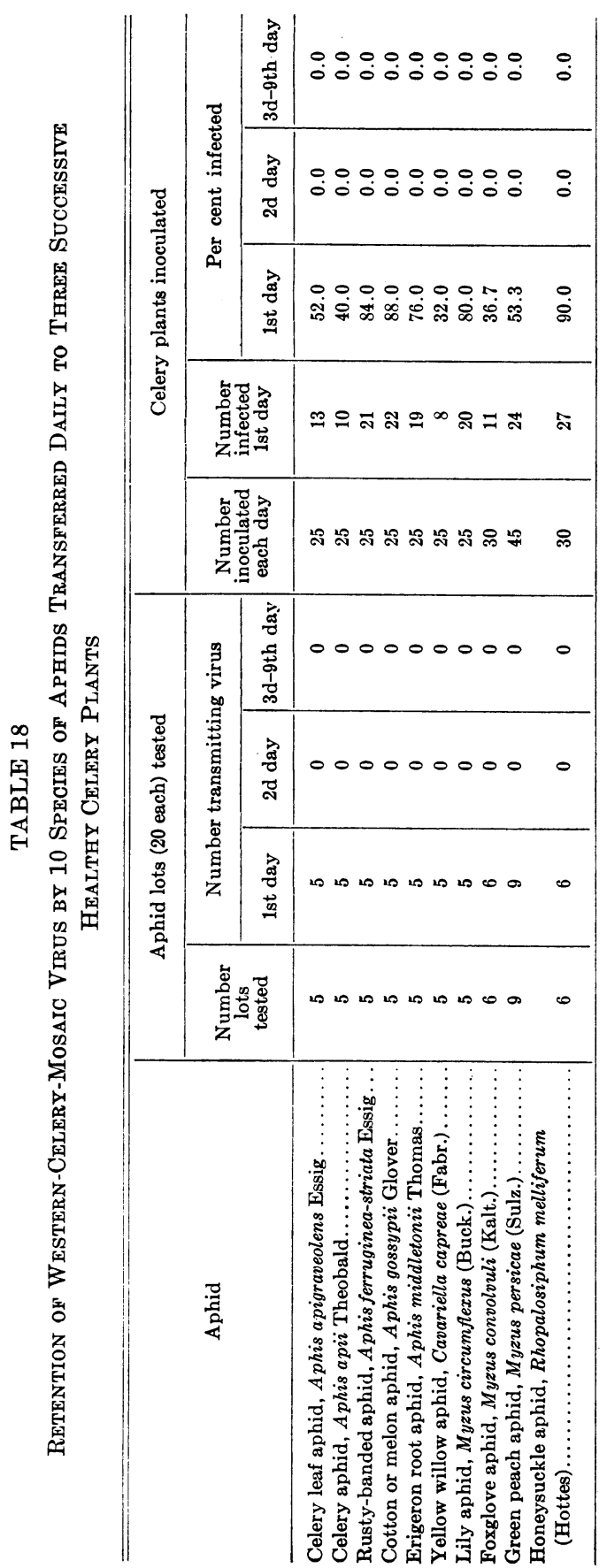




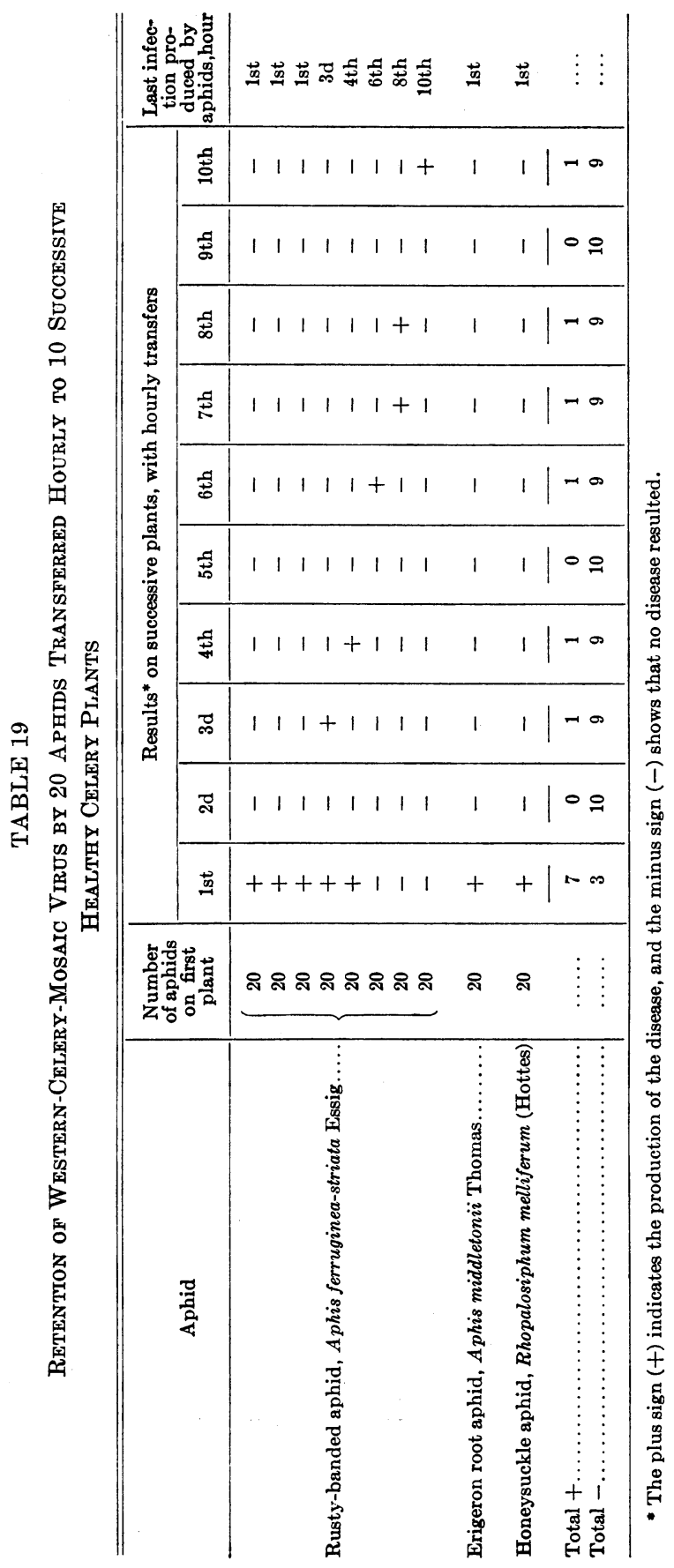


aphids infected the first set of healthy celery plants, on which they were kept for a period of 12 hours, but had lost the infective dose of the virus when transferred to the second set of healthy plants; no subsequent transmissions were obtained.

In the third experiment, 10 lots of 20 wingless aphids reared on diseased celery were transferred hourly with a moistened camel's-hair brush to 10 successive healthy celery plants. Eight lots of the rusty-banded aphids and 1 lot each of the erigeron root aphid and the honeysuckle aphid were tested. The mortality was low with the three species of aphids selected. As shown in table 19, 3 of the rusty-banded and 1 each of the other two species of aphids infected a celery plant during the first hour only, 2 lots infected plants during the first hour and again during the third or fourth hour, one lot infected a plant during the sixth hour, another lot infected 2 successive plants during the seventh and eighth hours only, and lastly 1 lot infected a plant during the tenth hour only.

In the last experiment, 18 single noninfective aphids were fed for varying periods on diseased celery and then each aphid was transferred hourly for a period of 8 hours and then daily until it died to successive healthy celery plants. The work with single aphids required many tests, most of which were negative. The positive results obtained with 10 different species of aphids during the hourly transfers are given in table 20. Four of the aphids infected only the first celery plant and then lost the infective power; 3 aphids infected the first plant, retained the infective dose of the virus, and infected a second plant. One erigeron root aphid (Aphis middletonii) infected celery plants during the fifth and eighth hours, retaining the virus 7 to 8 hours. The ten species of aphids transferred daily to healthy celery plants failed to infect a single plant. Some of the aphids died during the first day, others were transferred daily to healthy plants for over a month. One lily aphid was transferred daily to successive healthy celery plants for a period of 38 days.

Loss and Recovery of Infectivity by Aphids on Infected Plants.Since many growers rogue diseased celery from their fields, an attempt was made to determine whether different species of aphids were able to recover the virus from infected celery before the first symptom of the disease developed. A large population of aphids reared on a diseased celery plant was transferred to a healthy celery plant for 2 days. For a period of 12 days from the third to the fourteenth day, lots of 20 of these aphids were transferred daily from the plant so infected to healthy celery plants.

The loss and recovery of infectivity by aphids on celery inoculated with western celery mosaic and the incubation period of the disease or 


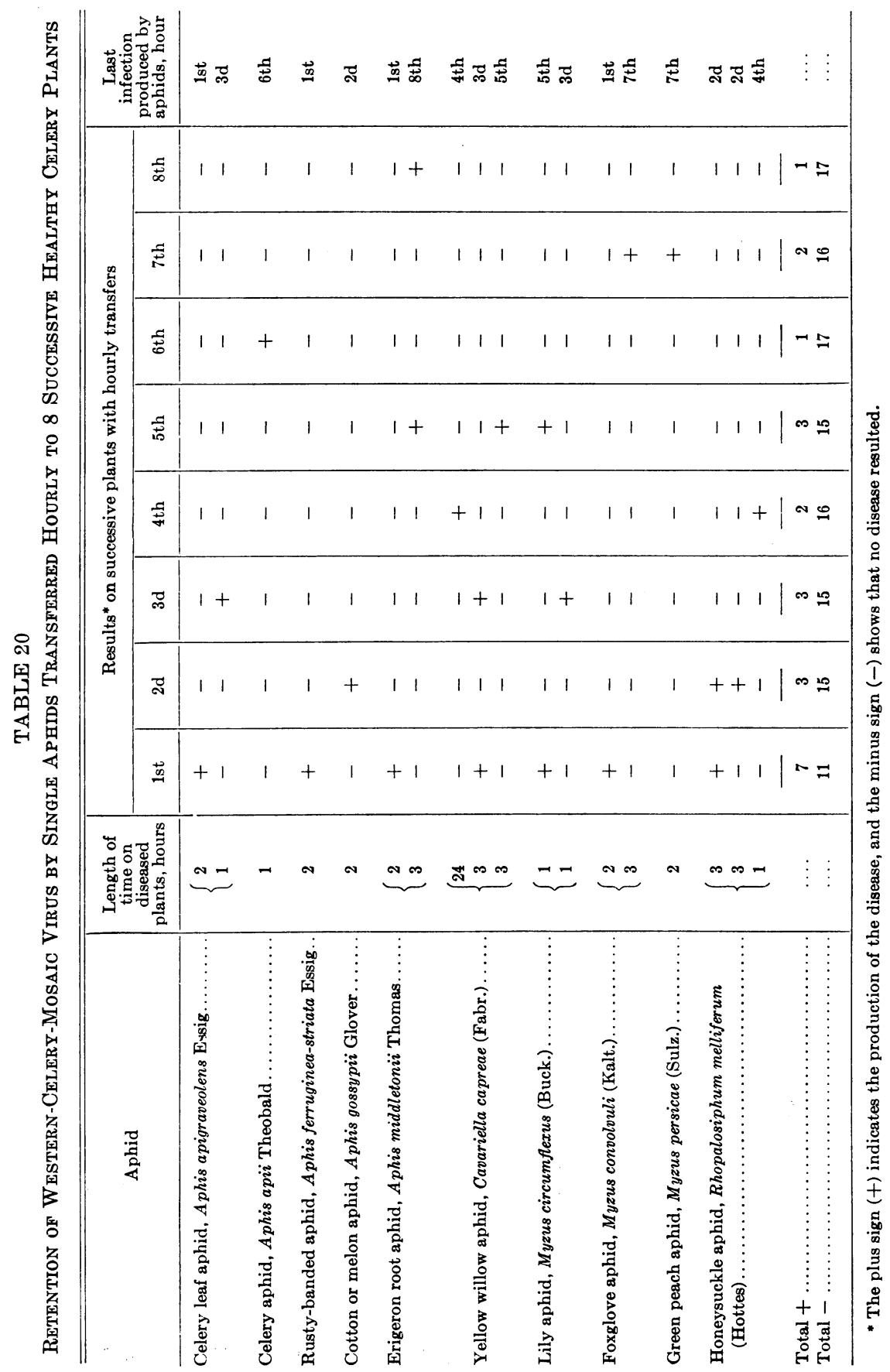




\begin{tabular}{|c|c|c|c|c|c|c|c|c|}
\hline & 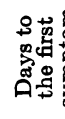 & & 은 눅 & $\infty$ & $\infty * \infty \quad \infty \quad \infty \quad \infty \quad \infty \infty \infty$ & $+\infty$ & $=0 \cong \infty$ & 응 \\
\hline$\frac{\pi}{2}$ & & 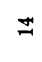 & $1+$ & + & $11+111+1+1$ & 11 & $1+11$ & $1+$ \\
\hline 卢 & 일 & $\dddot{m}$ & +1 & + & $1++111+t+t$ & 11 & $111+$ & ++ \\
\hline$\sum_{\dot{y}}^{0}$ & $\begin{array}{l}\text { ⿷ี } \\
\text { क } \\
\text { के }\end{array}$ & $\stackrel{9}{\sim}$ & 11 & + & $11+t+11+t+$ & 11 & $11+1$ & 11 \\
\hline 至 & 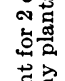 & 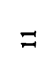 & 11 & + & $1+1++1+1+1$ & $1+$ & $\begin{array}{llll}1 & 1 & 1 & 1\end{array}$ & 11 \\
\hline $\begin{array}{l}\text { 異 } \\
\text { 界 } \\
\text { 空 }\end{array}$ & 进 & 오 & 11 & 1 & $1+++1+++11$ & ++ & $\begin{array}{llll}1 & 1 & 1 & 1\end{array}$ & $1+$ \\
\hline 罢 & 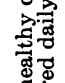 & $\infty$ & 11 & 1 & $\begin{array}{lllllll}1 & 1 & 1 & 1 & 1 & 1 & 1\end{array}$ & 11 & $\begin{array}{llll}1 & 1 & 1 & 1\end{array}$ & 11 \\
\hline 罢 & 矛兽 & $\infty$ & 11 & 1 & $+1+1 \quad 1 \quad 1 \quad 1 \quad 1 \quad 11$ & 11 & ++11 & 11 \\
\hline 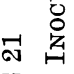 & 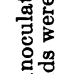 & r & 11 & 1 & $\begin{array}{llllllllll}1 & 1 & 1 & 1 & 1 & 1 & 1 & 1 & 1 & 1\end{array}$ & 11 & $\begin{array}{llll}1 & 1 & 1 & 1\end{array}$ & $1+$ \\
\hline 是 & 疍高 & $\infty$ & 11 & 1 & $\begin{array}{lllllllll}+ & 1 & 1 & 1 & 1 & 1 & 1 & 1 & 1\end{array}$ & 11 & $\begin{array}{llll}1 & 1 & 1 & 1\end{array}$ & 11 \\
\hline $\begin{array}{l}2 \\
0 \\
\text { \%月 } \\
\text { 㝵 }\end{array}$ & 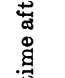 & هم: & 11 & 1 & $\begin{array}{llllllllll}1 & 1 & 1 & 1 & 1 & 1 & 1 & 1 & 1 & 1\end{array}$ & 11 & $\begin{array}{llll}1 & 1 & 1 & 1\end{array}$ & 11 \\
\hline$\frac{n}{4}$ & 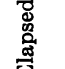 & 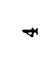 & 11 & 1 & $\begin{array}{llllllllll}1 & 1 & 1 & 1 & 1 & 1 & 1 & 1 & 1 & 1\end{array}$ & 11 & $\begin{array}{llll}1 & 1 & 1 & 1\end{array}$ & 11 \\
\hline$e_{-1}^{n}$ & & $\infty$ & 11 & 1 & $\begin{array}{llllllllll}1 & 1 & 1 & 1 & 1 & 1 & 1 & 1 & 1 & 1\end{array}$ & 11 & 11111 & 11 \\
\hline 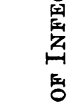 & 离 & & $\underbrace{r a}$ & $\infty$ & 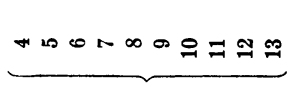 & $\underbrace{ \pm 2}$ & $\stackrel{2}{2} \approx \stackrel{\infty}{=}$ & ㅇํ \\
\hline 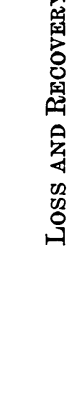 & & & 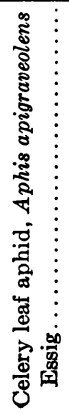 & 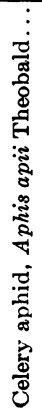 & 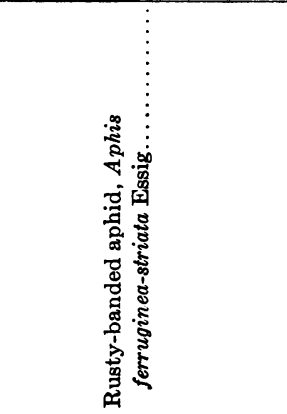 & 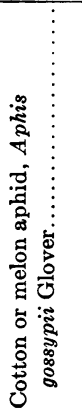 & 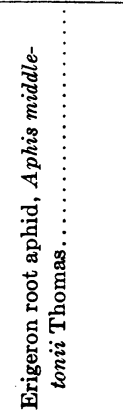 & 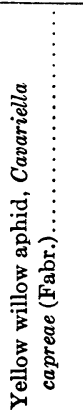 \\
\hline
\end{tabular}




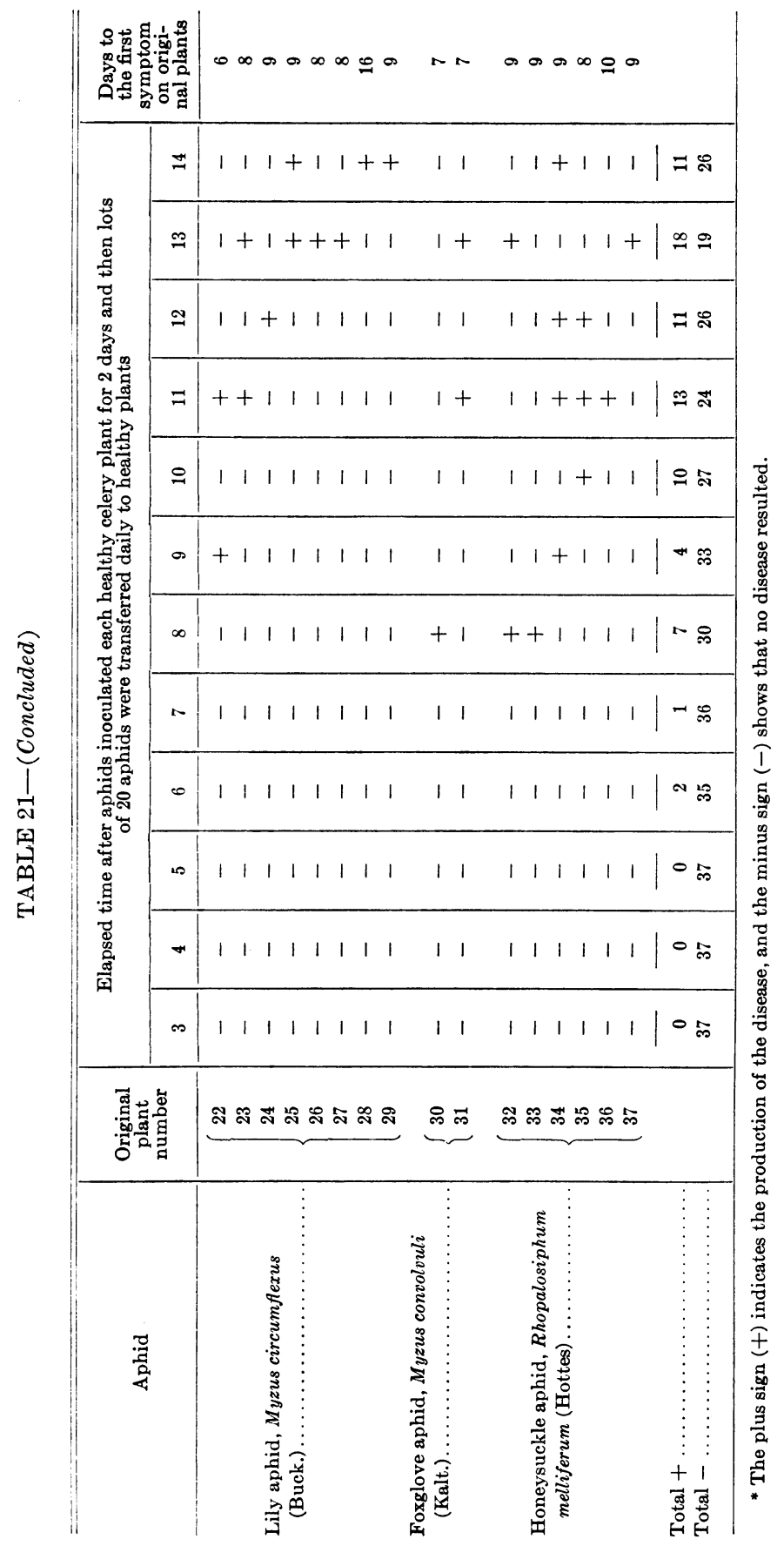


the period for the earliest symptom to develop, namely the cleared veinlets in the original infected celery plant, are shown in table 21. The elapsed time to the first recovery of the virus by different species of aphids from the original infected celery plants varied from 6 to 14 days. The incubation period of the disease in the original infected celery plants varied from 4 to 16 days. A comparison of the first recovery of the virus by lots of 20 aphids with the incubation period of the disease in the original infected celery plants shows that 6 of 37 lots of aphids recovered the virus before symptoms of the disease developed, 5 lots recovered the virus on the same day that the earliest symptom of the disease appeared, and 26 lots recovered the virus in from 1 to 6 days after the earliest symptom of the disease developed. An examination of the total number of positives shows that the maximum period of recovery of the virus by aphids occurred between 10 and 14 days.

\section{CONTROL}

Celery-Free Periods.-Milbrath $(18,19,20)$ claims that a celery-free period, adopted by agreement with the growers, has proved a practical method of combating celery mosaic in the Sawtelle and Venice districts.

TABLE 22

Celery-Free Periods in the Fields and Greenhouses in the Sawtelle and Venice Districts, Los Angeles Countr*

\begin{tabular}{|c|c|c|c|c|}
\hline \multirow{2}{*}{ Year } & \multicolumn{2}{|c|}{ Celery-free period in fields } & \multicolumn{2}{|c|}{ Celery-free period in greenhouses } \\
\hline & Dates & Months & Dates & Months \\
\hline $\begin{array}{l}1934 \ldots \ldots \ldots \ldots \\
1935 \ldots \ldots \ldots \ldots \\
1936 \ldots \ldots \ldots \ldots\end{array}$ & $\begin{array}{l}\text { July } 31 \text { to Jan. } 1 \\
\text { Aug. } 31 \text { to Dec. } 20 \\
\text { Sept. } 16 \text { to Dec. } 11\end{array}$ & $\begin{array}{l}5 \\
32 / 3 \\
32 / 3\end{array}$ & $\begin{array}{l}\text { Sept. } 1 \text { to Oct. } 20 \\
\text { Sept. } 15 \text { to Oct. } 15 \\
\text { Sept. } 16 \text { to Oct. } 16\end{array}$ & $\begin{array}{l}12 / 3 \\
1 \\
1\end{array}$ \\
\hline
\end{tabular}

*Source of data:

Milbrath, D. G., and Harold J. Ryan. A method of control of western celery mosaic. California State Dept. Agr. Mo. Bul. 27 (3): 290-95. 1938.

During the past three years, growers were prohibited from planting celery in the fields and greenhouses during the periods indicated in table 22.

During the celery-free period, all fields in the restricted area were plowed, and all plants not previously harvested were destroyed. No celery was allowed to be shipped into these districts from other localities during the celery-free period. The crops grown after the celery-free period thus far have shown tremendous improvement, and the growers are well satisfied, according to H. H. Wilcomb (Schraff, 27), who was in charge of control of celery mosaic in Los Angeles County, and also to Milbrath $(18,19,20)$ and Brock (2). 
Macmillan and Plunkett (59) reported their observations on western celery mosaic during the 1937 celery-growing season in the southern part of California. In the Venice section on May 25, in "fields approaching harvest mosaic is general and severe." On June 18, mosaic "varied widely from field to field, some having as much as 50 per cent severely infected plants." On August 13, "mosaic is common in the field." On September 16 , celery "plants about 6 inches high showed 80 per cent infection with mosaic throughout several fields near Redondo." No case of mosaic was observed on wild or escaped celery growing in the Los Angeles River bottom and in marshy places in valley bottoms, and in desert surroundings in San Diego County where seepage supplies constant water.

Observations in Santa Clara Valley indicate that celery plants may show a high percentage of disease and yet make a profitable crop. The percentage of diseased plants is of little economic importance if celery plants are infected when large. Small celery plants showing 80 per cent infection at Redondo would result in a loss or total failure, but Redondo is outside of the restricted area in which the celery-free period has been reported as a success in combating western celery mosaic. According to table 1 (p. 495), the yield per acre was increased during 1936 and 1937 after the adoption of the celery-free period in the Venice and Culver districts.

Planting Time.-Ryan (25) reported that many fields were 100 per cent infected with western celery mosaic in the Venice district in the fall of 1932, and that during the spring of 1934 celery was a total failure because of the disease.

Observations in the Santa Clara Valley indicate that celery grown in the greenhouse and transplanted in the field in March showed a low percentage of diseased plants when harvested in June. When low temperatures prevailed, however, early-planted celery often developed seedstalks. Celery transplanted during April and May showed a high percentage of infected plants when harvested during July and August. Successive plantings of celery showed a gradual increase in the percentage of diseased plants during late spring and early summer. Celery transplanted during August and September, on the other hand, was not usually seriously affected with the disease unless it was grown adjacent to celery which showed a high percentage of infected plants. Celery transplanted adjacent to larger plants which showed a high percentage of infected plants usually results in a loss.

The fact that celery which matures in July and August is usually severely damaged has suggested a celery-free period during these two months in the Santa Clara Valley. Such a practice would eliminate the 
summer celery, which has not proved profitable, and might aid in lowering the percentage of infection on the autumn celery. When weeds become dry in the cultivated areas during the summer, enormous numbers of winged aphids fly into the celery fields and spread the virus of western celery mosaic to summer celery.

Reservoirs of Virus.-The natural host range of western celery mosaic among economic plants so far determined includes carrots and celeriac. Celery should not be planted adjacent to carrots or celeriac.

No weed hosts of the virus of western celery mosaic have been found under natural conditions up to the present time. The extracts from many weeds with mosaic symptoms have been inoculated in healthy celery, but all efforts to find a weed reservoir of the western-celery-mosaic virus were failures. Since transmission of the virus from celery can be accomplished more readily by aphids than by mechanical inoculation of diseased juice, further investigations on the weed host range have been undertaken. Observations indicate that there is usually a higher percentage of diseased celery along the margin of the celery fields adjacent to weeds.

Weed Eradication.-The eradication of weeds in and surrounding celery fields will reduce the population of aphids. Poison hemlock or spotted parsley (Conium maculatum), a tall, rank, poisonous, much-branched herb, abundant in the Santa Clara Valley, is one of the most favorable breeding plants of the honeysuckle aphid (Rhopalosiphum melliferum), and enormous populations developed on it. The rusty-banded aphid (Aphis ferruginea-striata) also breeds on it. It has been demonstrated to be naturally infected with three virus diseases of celery-yellow spot, ringspot, and California aster yellows (fig. 9), hence the importance of its eradication in the vicinity of celery fields. One grower sprayed this weed with oil to destroy it in the vicinity of his celery field.

The following paragraph on the distribution of poison hemlock is quoted from Sampson and Malmstem (26):

Poison hemlock, although indigenous to Europe and Asia, has spread until it is widely distributed throughout California and the northwestern United States. It is confined almost wholly to waste places, growing on moist, shady, or fairly dry ground, in fields and canyons, and along dusty roadsides. It is in no way semiaquatic like water hemlock. Although primarily a low-altitude species, the range in elevation is from sea level to 7,500 feet.

Sweet fennel (Foeniculum vulgare), a perennial of short duration, cultivated as an annual or biennial, common in vacant fields and roadsides, is a favorable breeding plant of the celery aphid (Aphis apii), rusty-banded aphid, and the yellow willow aphid (Cavariella capreae). 
It can be controlled by hoeing off the stems two or three times a season as near the surface of the ground as possible (33).

Roguing.-When a low percentage of western celery mosaic appears in the fields, some growers practice roguing of infected plants to pre-

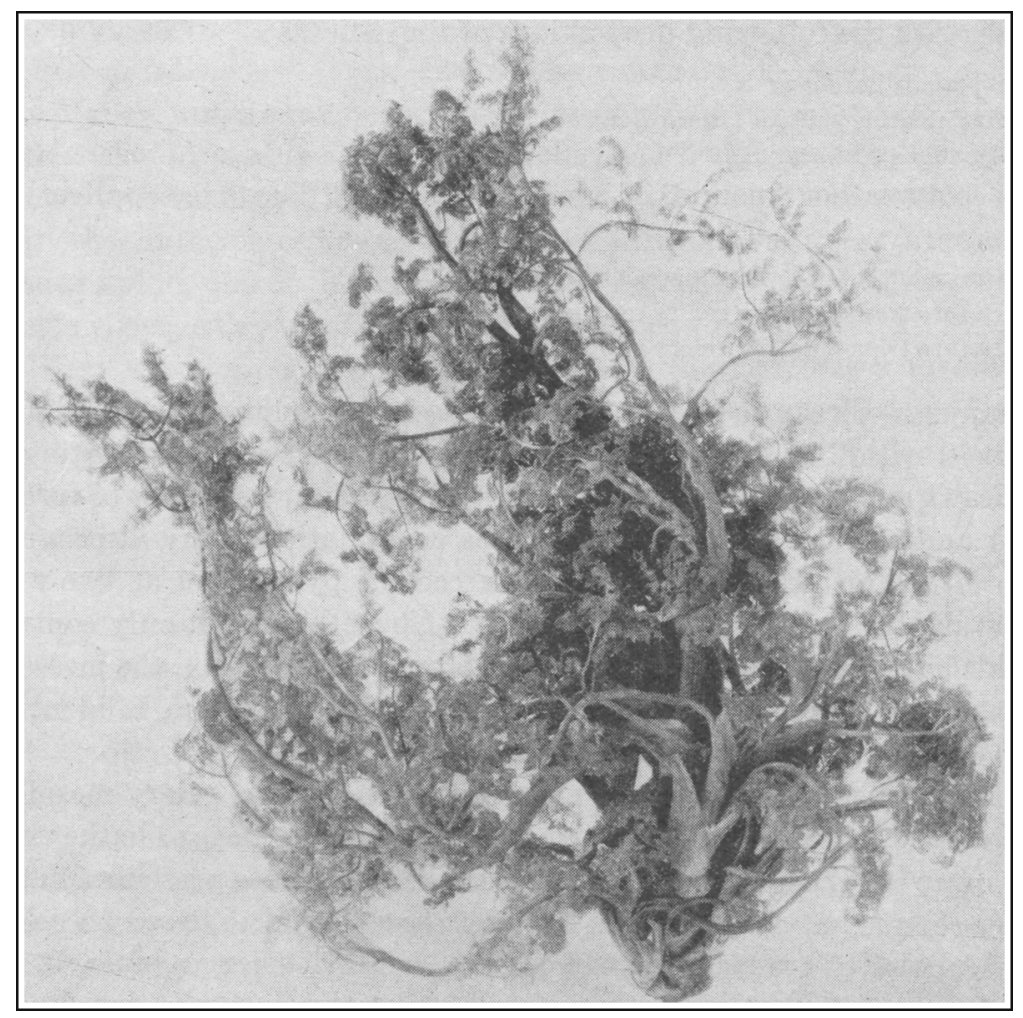

Fig. 9.-Poison hemlock (Conium maculatum) naturally infected with California aster yellows, showing twisted petioles (Alvarado, March 3, 1936).

vent the spread of the disease by aphids. One grower collected the diseased plants in a large basket and destroyed them by burning with oil. It is evident, however, that aphids can recover the virus from infected plants before the earliest symptom of the disease develops.

Abandoned Mosaic-Celery Fields.-Celery fields which are not worth harvesting owing to western celery mosaic should be plowed under as soon as possible. The abandoned fields if not destroyed are a menace to neighboring fields as a source of virus. All fields should be plowed shortly after cutting celery so that no abandoned diseased celery plants remain after harvesting is completed. 
Spraying.-The spray programs have been conducted by the growers, and since no unsprayed check or control plots were used, no statement ean be made about the value of the sprays used to control aphids in relation to western celery mosaic. One grower employed three applications of a combination spray on celery seedlings grown in flats in the greenhouse, with the following proportions of ingredients :

6-8 pounds bordeaux

1 pint nicotine sulfate (Black Leaf 40 )

100 gallons of water

In cool weather 8 pounds of bordeaux was used. The three applications of the spray were as follows :

1. One month after planting celery seeds.

2. Before transplanting celery seedlings in flats.

3. Before transplanting celery seedlings in the field.

Many growers in the Santa Clara Valley spray celery transplanted in the field with 2 or 3 applications of a combination spray consisting of bordeaux and nicotine sulfate to control late blight of celery (Septoria apii) and aphids. One grower used the combination spray alternating with either nicotine sulfate or the extract of pyrethrum at two-week intervals. It is believed that the extract of pyrethrum not only controls aphids but also the aster leafhopper (Macrosteles divisus), the most important leafhopper vector of celery-yellows virus (which is identical with the virus of California aster yellows).

The problem of aphid control in relation to western celery mosaic is complicated, and no definite statement can be made in regard to the value of a spray program up to the present time. The evidence presented in this paper shows that aphids which have not been found to breed on celery were capable of transmitting the virus of western celery mosaic. It is a well-known fact that when the pasture vegetation becomes dry during the spring on the uncultivated foothills, large flights of aphids occur in the cultivated areas. When weeds become dry in the cultivated areas during the summer, large populations of winged aphids have been collected in celery fields. Many of the aphids which have been reared on celery breed on a large number of other host plants, as recorded by Essig (7) in the preceding paper. It must also be noted that the erigeron root aphid (Aphis middletonii) and the rusty-banded aphids are root-feeding forms which cannot be controlled by spraying the foliage of celery.

Cold Frames.-Some growers remove the flats of celery seedlings from the greenhouse and allow the plants to harden out of doors for several weeks before transplanting in the field. Different species of aphids, as well as western-celery-mosaic infection, were found on celery seedlings 
grown in flats and kept out of doors. The flats of celery seedlings should be placed in cold frames covered with muslin.

Some growers plant celery seeds in beds out of doors. An examination of celery seed beds showed the presence of aphids and of mosaic plants. Celery seedling should be grown in cold frames where small acreages are transplanted.

Dissemination.-Western celery mosaic does not occur in the San Joaquin Valley, and no celery seedlings unless grown outside of an infected district should be shipped into this valley. Although western celery mosaic is a serious disease in the Fog Belt of California, it is known to thrive in the hot interior regions such as the Sacramento Valley. The rustybanded aphid, one of the most important carriers of the western-celerymosaic virus, is known to occur in the San Joaquin Valley.

Celery was shipped from Florida to California and was transplanted in the field during 1936 in the Salinas Valley for seed production. Celery has also been shipped from Florida to growers in the Santa Clara Valley, but up to the present time southern celery mosaic is not known to occur in California.

\section{DISCUSSION}

A comparison of the host ranges of southern- and western-celery-mosaic viruses indicates that the two viruses are not identical. Inoculation experiments demonstrated that the southern-celery-mosaic virus may infect 91 different host plants, comprising 23 families of plants. Of the susceptible host plants, 46 have been found naturally infected in the field (40). Host-range studies of the western-celery-mosaic virus indicate that susceptible host plants are limited to plants of the family Umbelliferae. Carrots (Daucus Carota var. sativa) and celeriac (Apium graveolens var. rapaceum) are susceptible to both southern and western celery mosaic, but Hollow Crown and Long Smooth parsnips (Pastinaca sativa), susceptible to the former, are immune to western celery mosaic.

A comparison of the properties of the viruses of southern and western celery mosaic shows that the two viruses are distinct. Wellman (36) found that the extract from southern celery mosaic was infective after treatment at $65^{\circ} \mathrm{C}$ for 10 minutes, and occasional samples of viruliferous juice from tobacco and cucumber plants infected with southern celery mosaic were infective at $75^{\circ}$, but in all cases the virus was inactivated at $80^{\circ}$. The virus of western celery mosaic remained infective after heating the expressed juice at $55^{\circ}$ for 10 minutes but was inactivated at $60^{\circ}$.

Wellman (36) produced infections with the following dilutions from plants infected with southern celery mosaic: celery $1: 1,000$, tobacco $1: 10,000$, and cucumber $1: 100,000$. The tolerance to dilution of the virus in juice extracted from western-celery-mosaic plants was $1: 4,000$. 
Wellman (36) considers the virus causing southern celery mosaic a new one and has given it the designation "celery virus 1." Southern celery mosaic is similar in some ways to cucumber mosaic (cucumber virus 1, Doolittle) described by Doolittle (3), Johnson (14) and Doolittle and Walker (4) in host and symptomatological relations and in properties. The thermal inactivation of southern-celery-mosaic virus is only $5^{\circ} \mathrm{C}$ higher than the cucumber-mosaic virus. The southern-celerymosaic virus, however, withstands aging in vitro from 6 to 8 days whereas the cucumber-mosaic virus withstands the treatment only about 3 days.

The virus causing southern celery mosaic should be designated as a strain of cucumber mosaic.

The evidence presented in this paper shows that the viruses of southern and western celery mosaics are not identical. There is no evidence to show that the virus of western celery mosaic is a strain of cucumber mosaic. The virus causing western celery mosaic is new; a description follows :

\section{DESCRIPTION OF WESTERN-CELERY-MOSAIC VIRUS}

Name: Western celery mosaic. ${ }^{\circ}$

Host family: Umbelliferae.

Symptoms of disease: On celery, vein clearing, followed by mottling, necrotic spotting, white spots or streaks on petioles, stunting of plant.

Incubation period of disease: 10 to 16 days or longer out of doors.

Property studies: Filterable through all grades of Chamberland filters, thermal inactivation $60^{\circ} \mathrm{C}$ in 10 -minute exposure, tolerance to dilution $1: 4,000$, resistance to aging in vitro 7 days, resistance to 30 per cent alcohol supernatant liquid 1 hour, 40 per cent alcohol precipitate 1 hour.

Modes of transmission: mechanical inoculation with expressed juice, in nature by 11 species of aphids which breed on celery, no specific aphid vector.

\section{SUMMARY}

The following virus diseases of celery occur under natural conditions in California : western celery mosaic, celery calico, celery yellow spot, celery crinkle-leaf, celery yellows (the virus is identical with California aster yellows), and spotted wilt. Celery has been experimentally infected with the viruses of sugar-beet curly top and poison hemlock ringspot.

The host range of western celery mosaic is limited to the family Umbelliferae, to which celery belongs. The following economic plants have been demonstrated to be naturally infected with western celery mosaic up to the present time: varieties of celery (Apium graveolens var. dulce), celeriac (Apium graveolens var. rapaceum), and varieties of carrots

\footnotetext{
${ }^{6}$ Smith (34) classifies the western-celery-mosaic virus as a synonym of Apium Virus 1, Severin and Freitag.
} 
(Daucus Carota var. sativa). The host range as determined by experimental infection, by juice inoculation and by infection by aphids consists of the following economic plants : Large Smooth Prague celeriac (Apium graveolens var. rapaceum), dill (Anethum graveolens), Curled chervil (Anthriscus Cerefolium), caraway (Carum carvi), coriander (Coriandrum sativum), varieties of carrots (Daucus Carota var. sativa) and Single or Plain parsley (Petroselinum hortense).

Mechanical inoculations of healthy celery plants with the juice from the leaves of mosaic carrots resulted in lower percentages of infections than those with juice from the roots.

The virus was more readily recovered from symptomless carriers of Single or Plain parsley by mechanical inoculation (42.9 per cent) than by the rusty-banded aphid (Aphis ferruginea-striata) (5.7 per cent).

Mechanical inoculation of cucumber plants with the extract from celery infected with western celery mosaic collected in 23 localities of California, and attempts to transmit the virus by $\mathbf{1 1}$ species of aphids from naturally infected celery were failures.

Some of the properties of the virus are summarized as follows: The virus of western celery mosaic passed through all grades of Chamberland filters. The thermal inactivation of the western-celery-mosaic virus was $60^{\circ} \mathrm{C}$ in 10-minute exposures. Freezing juice extracted from naturally infected celery kept in cold storage at $-18^{\circ} \mathrm{C}$ did not inactivate the virus after 18 months. The tolerance to dilution of extracted diseased celery juice was $1: 4,000$. An inactivation of the virus occurs after extracted diseased celery juice was exposed to the air at room temperature for a period of 7 days. The western-celery-mosaic virus in the supernatant liquid was capable of withstanding treatment with 30 per cent alcohol and the precipitate with 40 per cent alcohol for 1 hour.

Six species of aphids which have not been found to breed on celery under field conditions were capable of transmitting the virus of western celery mosaic (table 12, p. 520).

Eleven species of aphids which breed on celery under natural conditions transmitted the virus of western celery mosaic; there is no specific aphid vector of the virus. A summary of the percentages of infections obtained with the different species is given in table 16 , page 528 .

The transmission of the virus by 11 species of aphids from naturally infected to healthy celery plants varied from 2.2 per cent to 92.5 per cent and by mechanical inoculation of juice extracted from the same naturally infected plants on which the aphids were reared averaged 48.2 per cent (table 15, p. 527) and in another experiment 53.8 per cent (table 4, p. 514). 
The highest percentage of infections by single winged aphids was 7.0, produced by the celery-leaf aphid (Aphis apigraveolens) and by single wingless mature aphids 37.3 , produced by the rusty-banded aphid ( $A$. ferruginea-striata).

Ten species of aphids transmitted the virus from diseased to healthy celery plants during the first day, but 56 lots of 20 aphids tested had lost the infective power by the second day.

Five lots of 20 rusty-banded aphids (Aphis ferruginea-striata) infected the first set of healthy celery plants on which they were kept for a period of 12 hours, but when transferred hourly to successive sets of plants for a period of 8 hours, no infections occurred.

The retention of the virus by single infective wingless aphids varied from 1 to 8 hours and by lots of 20 infective aphids from 1 to 10 hours.

In some instances, aphids recovered the virus from celery infected with western celery mosaic before symptoms of the disease developed, in some on the same day after the earliest symptoms of the disease appeared, and in others in from 1 to 6 days after the first symptoms of the disease developed.

\section{ACKNOWLEDGMENTS}

The assistance of nontechnical employees of the W.P.A. is acknowledged. 
BRock, A. A.

\section{LITERATURE CITED}

1935. Report of Director of Agriculture. California State Dept. Agr. Mo. Bul. 24:13.

2 Brock, A. A.

1936. Report of Director of Agriculture. California State Dept. Agr. Mo. Bul. 25:10.

${ }^{3}$ Doolitwre, S. P.

1920. The mosaic disease of eucurbits. U. S. Dept. Agr. Bul. 879:1-69.

4 Doolititle, S. P., and M. N. Walker.

1925. Further studies on the overwintering and dissemination of cucurbit mosaic. Jour. Agr. Research 31:1-58.

"Doolittre, S. P., and F. L. Wellman.

1934. Commelina nudiflora, a monocotyledonous host of a celery mosaic in Florida. Phytopathology 24:48-61.

${ }^{8}$ Elmer, O. H.

1925. Transmissibility and pathological effects of the mosaic disease. Iowa Agr. Exp. Sta. Res. Bul. 82:37-91.

${ }^{7}$ Essig, E. O.

1937. Aphids feeding on celery in California. Hilgardia 11(9):459-92.

${ }^{8}$ Fleury, A. C.

1934. Proceedings of the fifteenth and sixteenth annual conferences, Western Plant Quarantine Board 1933-1934. California State Dept. Agr. Mo. Bul. 23:287.

${ }^{\circ}$ Foster, A. C., and G. F. WebBer.

1924. Celery diseases in Florida. Florida Agr. Exp. Sta. Bul. 173:21-78.

${ }^{10}$ Gardner, M. W.

1923. Indiana plant diseases, 1921, 1922. Indiana Acad. Sci. Proc. 33:177, 205.

${ }^{11}$ Gardner, M. W., C. M. Tompkins, and O. C. Whipple.

1935. Spotted wilt of truck crops and ornamental plants. Phytopathology 25:17.

12 Gigante, $R$.

1936. Il mosaico del sedano [Celery mosaic]. Bol. Staz. Path. Veg. Roma, n. s. 16:99-114. Abstracted in: Rev. Appl. Mycol. 16:227-28. Rev. Appl. Ent. 24:799.

${ }^{13}$ Harvey, R. B.

1925. Blanching celery. Minnesota Agr. Exp. Sta. Bul. 222:1-20.

${ }^{14}$ JoHNSON, J.

1927. The classification of plant viruses. Wisconsin Agr. Exp. Sta. Res. Bul. $76: 1-16$.

15 Johnson, J., and T. J. Grant.

1932. The properties of plant viruses from different hosts. Phytopathology 22: 741-57.

${ }^{10}$ KeIFER, H. H.

1936. Proceedings of the California Entomology Club. California State Dept. Agr. Mo. Bul. 25:395. 
${ }^{17}$ Milbrath, D. G.

1933. Bureau of Plant Pathology. California State Dept. Agr. Mo. Bul. 22:523.

${ }^{18}$ Milbrath, D. G.

1934. Mosaic disease on celery. California State Dept. Agr. Mo. Bul. 23:476-77.

${ }^{10}$ Milbrath, D. G.

1935. Western celery mosaic. California State Dept. Agr. Mo. Bul. 24:500.

${ }^{20}$ Milbrath, D. G.

1936. Celery mosaic. California State Dept. Agr. Mo. Bul. 25:578.

*1 Milbrath, D. G.

1937. Virus diseases of plants in relation to agriculture. California State Dept. Agr. Mo. Bul. 26:269-74.

$\because 2$ POOLE, R. F.

1922. Celery mosaic. Phytopathology 12:151-54.

${ }^{23}$ PRICE, W. C.

1935. Classification of southern-celery-mosaic virus. Phytopathology 25:947-54.

"2 Rawlins, T. E., and C. M. Tompkins.

1936. Studies on the effect of carborundum as an abrasive in plant virus inoculations. Phytopathology 26:578-87.

${ }^{25} \mathrm{RYAN}, \mathrm{H} . \mathrm{J}$.

1935. Celery mosaic. California State Dept. Agr. Mo. Bul. 24:273-74.

${ }^{20}$ Sampson, A. W., and H. E. Malmsten.

1935. Stock-poisoning plants of California. California Agr. Exp. Sta. Bul. 593: 1-90.

${ }^{2}$ SCHRAFT, J.

1936. Celery mosaic. California Cultivator 83(24):818-19.

${ }^{28}$ Severin, H. H. P.

1929. Yellows disease of celery, lettuce, and other plants, transmitted by Cicadula sexnotata (Fall.). Hilgardia 3(18):543-83.

${ }^{20}$ Severin, H. H. P.

1930. Life history of beet leafhopper, Eutettix tenellus (Baker) in California. Univ. California Pubs. Ent. 5:37-88.

${ }^{30}$ Severin, H. H. P.

1934. Transmission of California aster and celery-yellows virus by three species of leafhoppers. Hilgardia 8(10):339-61.

${ }^{31}$ Severin, H. H. P., and J. H. Freitag.

1933. Some properties of the curly-top virus. Hilgardia 8(1):1-48.

${ }^{32}$ Severin, H. H. P., and J. H. Freitag.

1935. California celery-mosaic diseases. Phytopathology 25:891.

${ }^{33}$ Smiley, F. J.

1922. Weeds of California and methods of control. California State Dept. Agr. Mo. Bul. 11(2-3):74-360.

${ }^{34}$ SMITH, K. M.

1937. A textbook of plant virus diseases. 615 p. P. Blakiston's Son \& Co. Inc. 1012 Walnut Street, Philadelphia. 
${ }^{35}$ Wellman, F. L.

1932. Celery-mosaic control in Florida by eradication of the wild host Commelina nudiflora. Science n. s. 76(1974):390-91.

"3isliman, F. L.

1934. Identification of celery virus 1 , the cause of southern celery mosaic. Phytopathology 24:695-725.

${ }^{37}$ Wellman, F. L.

1934. A disease of banana, markedly similar to bunchy top, produced by celery virus 1 in U. S. A. Phytopathology $24: 1032-34$.

${ }^{38}$ Wellman, F. L.

1934. Infection of Zea mays and various other Gramineae by the celery virus in Florida. Phytopathology 24:1035-37.

${ }^{39}$ Wellman, F. L.

1935. Dissemination of southern-celery-mosaic virus on vegetable crops in Florida. Phytopathology 25:289-308.

${ }^{40}$ Wellman; F. L.

1935. The host range of the southern-celery-mosaic virus. Phytopathology 25: $377-404$.

\section{APPENDIX TO CITATIONS}

Brief notes of the occurrence of celery mosaic in the United States have appeared from time to time in the Plant Disease Reporter. ${ }^{7}$ Frequently the collaborators of these reports were not mentioned, and it was found more convenient to list them in the chronological order rather than under the names of collaborators and editors.

41. The Plant Disease Bulletin Suppl. 3:108. 1919.

42. The Plant Disease Bulletin Suppl. 22:406. 1922.

43. The Plant Disease Reporter Suppl. 26:2, 149. 1923.

44. The Plant Disease Reporter 8:10. 1924.

45. The Plant Disease Reporter Suppl. 34:213. 1924.

46. The Plant Disease Reporter 9:58. 1925.

47. The Plant Disease Reporter Suppl. 41:275. 1925.

48. The Plant Disease Reporter Suppl. 45:98. 1926.

49. The Plant Disease Reporter Suppl. 54:303. 1927.

50. The Plant Disease Reporter Suppl. 59:87. 1928.

51. The Plant Disease Reporter Suppl. 61:277. 1928.

52. The Plant Disease Reporter Suppl. 84:39. 1933.

53. The Plant Disease Reporter Suppl. 85:52. 1933.

54. The Plant Disease Reporter 17:177-81. 1933.

55. The Plant Disease Reporter Suppl. 86:56. 1935.

56. The Plant Disease Reporter Suppl. 90:82. 1935.

57. The Plant Disease Reporter 19:106. 1935.

58. The Plant Disease Reporter Suppl. 96:193. 1936.

59. The Plant Disease Reporter 21:77-79. 1937.

${ }^{7}$ A mimeographed pamphlet issued by the United States Department of Agriculture, Bureau of Plant Industry. Early issues of this publication appeared under the name Plant Disease Bulletin. 

PLATES 



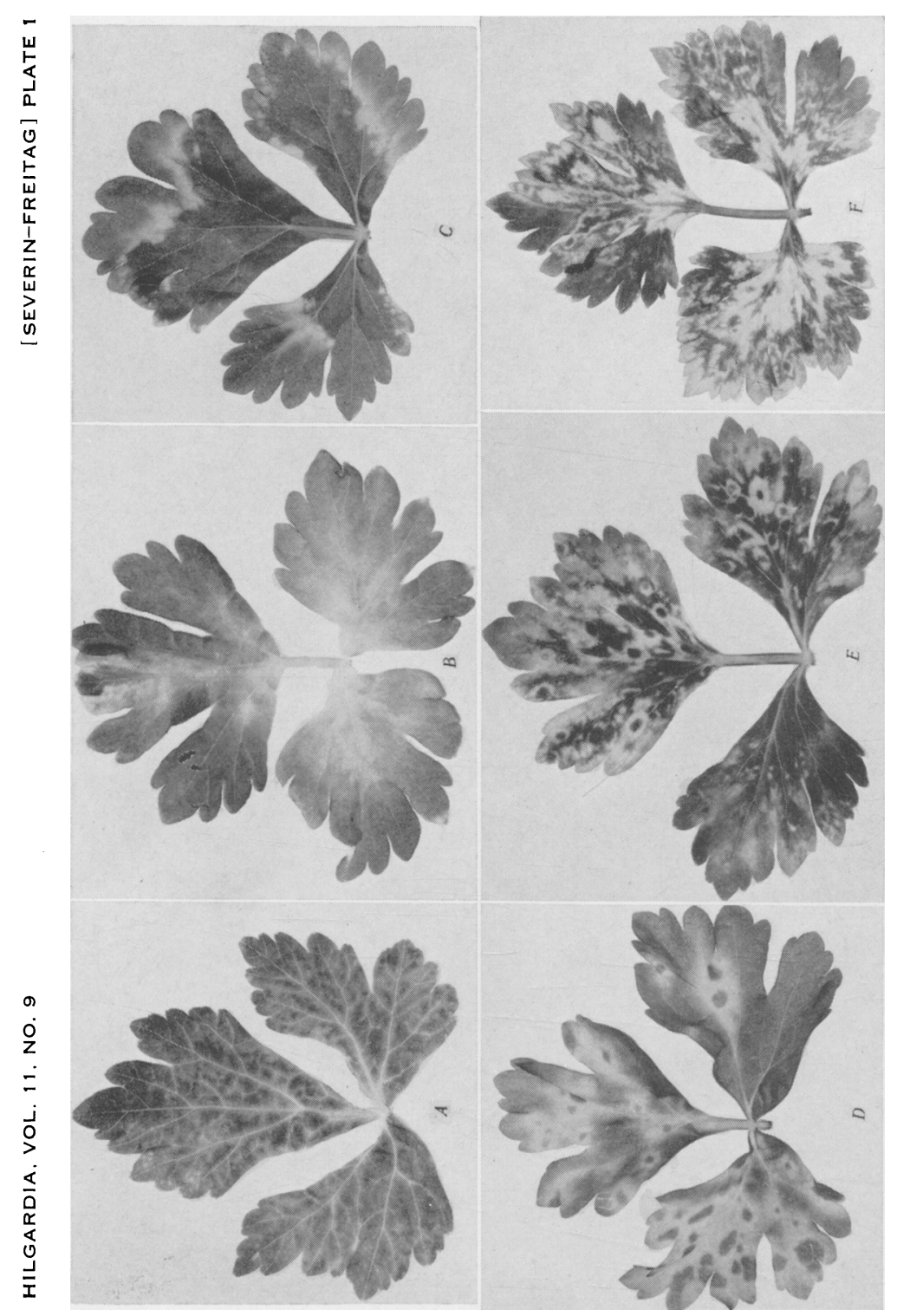

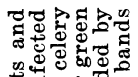
wa. g.

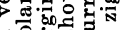
o 2 ) कृ

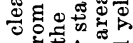
कo 5 .

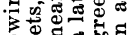
का 1) 응 -1 is E

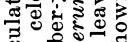
ठั. : ฐू. I)

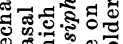

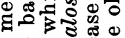

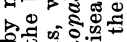
s 4 웅 공 . 0 :

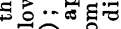
영 E. 品

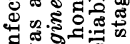
$\Rightarrow$ 요 겅 है효 ․ㅜㄹ. का

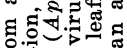

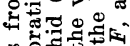
咆 웅 क्ष. Q $-7$. .. 800 कै क0 o O웅 1 $-\sigma^{5} a^{2}$ \&

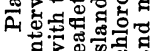




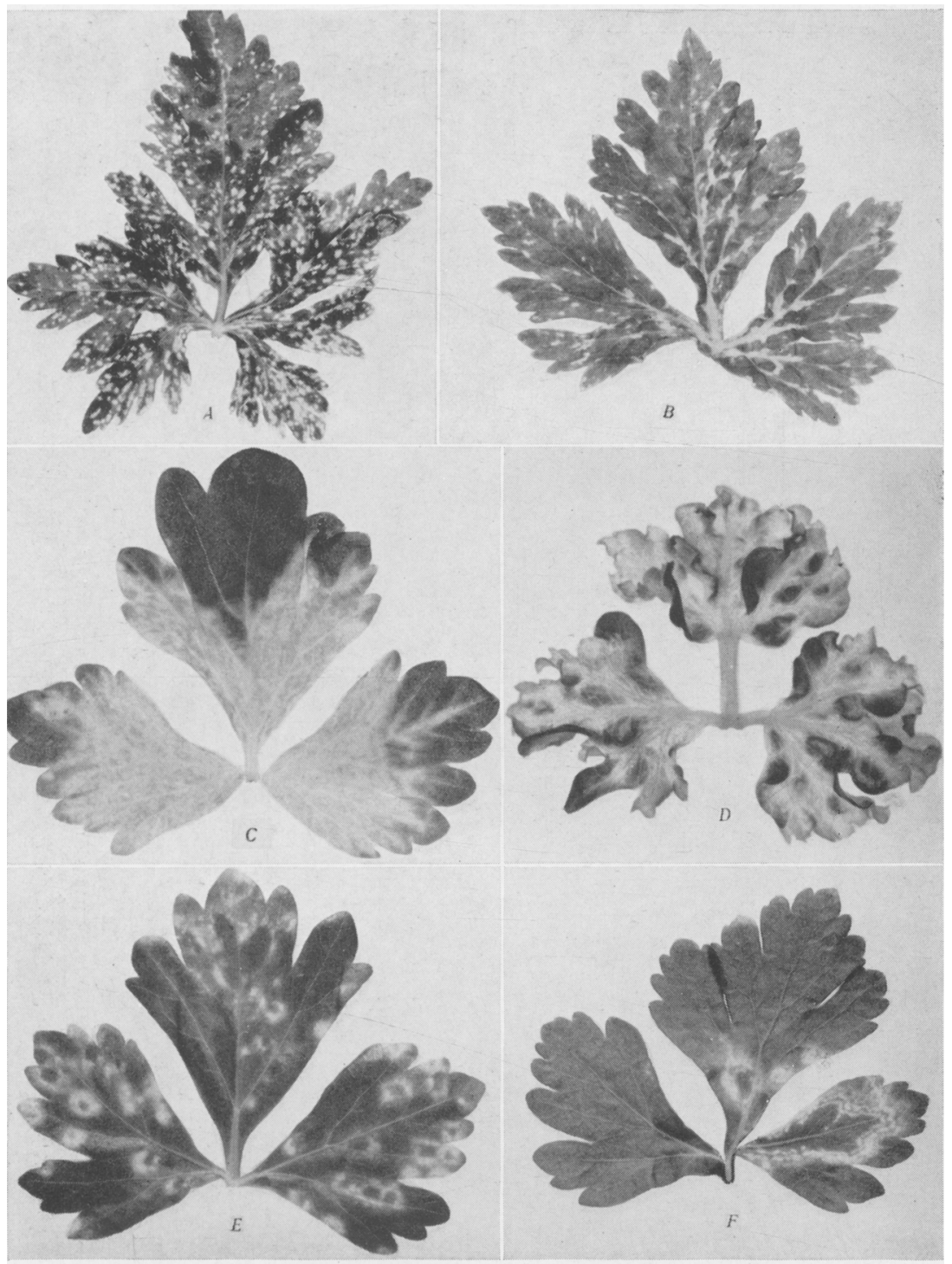

Plate 2.-A and $B$, Celery yellow spot: $A$, numerous chlorotic spots on the leaflets from a plant naturally infected with the disease (Milpitas, June 13, 1935); $B$, yellow stripes or bands along the veins from a plant naturally infected with the disease (Hollister, November 21, 1935). $C$, Leaflets from a plant experimentally infected with celery-crinkle-leaf virus showing cleared veinlets in chlorotic areas. $D$, Leaflets showing crinkling and blisterlike elevations. $E$ and $F$, Poison-hemlock ringspot on celery leaflets: $E$, small chlorotic rings enclosing green spots: $F$, large irregular green areas surrounded by alternating yellow and green lines. 


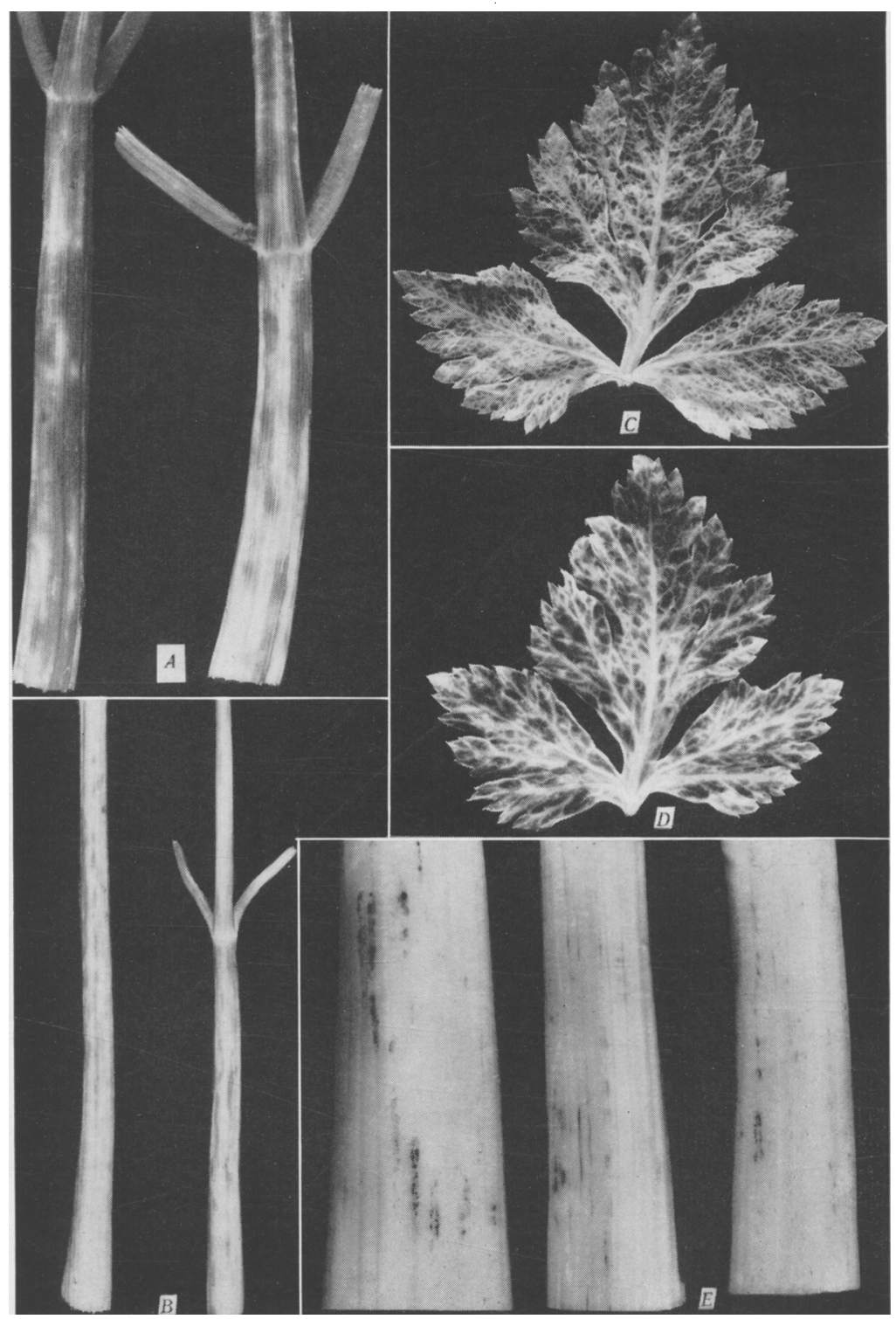

Plate 3.-A to $D$, Western celery mosaic: $A$, petioles showing white spots from a plant naturally infected '(Milpitas, June 13, 1935); $B$, petioles showing longitudinal white streaks from plants experimentally infected by the cotton or melon aphid (Aphis gossypii); $C, D$, leaflets from plants naturally infected showing cleared veins and veinlets and puckering (Mountain View, October 16, 1934) $E$, Epidermis removed from three petioles, showing brown specks along the veins from a plant naturally infected with celery yellow spot (Milpitas, November 18, 1934, courtesy of M. W. Gardner). 


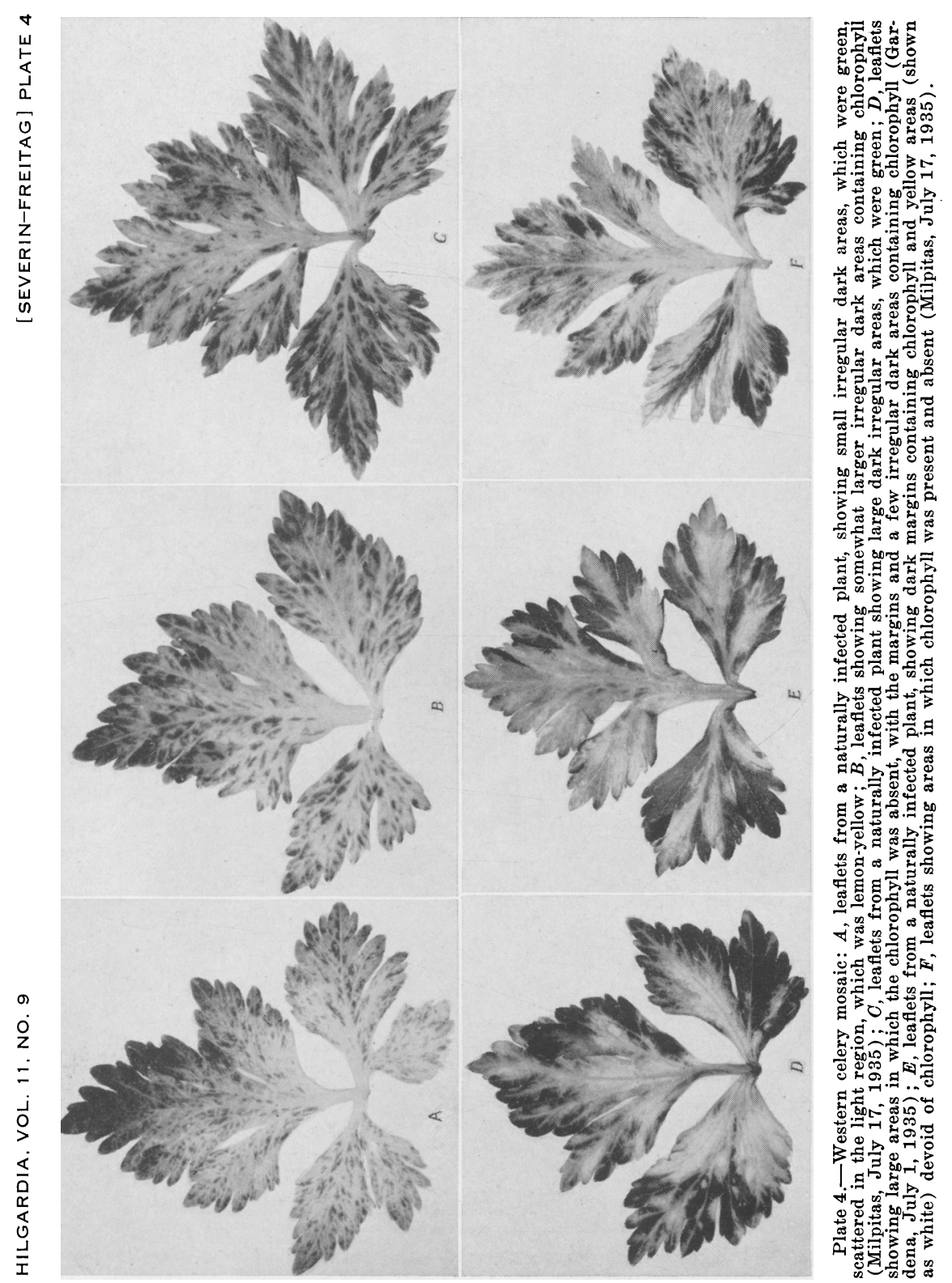




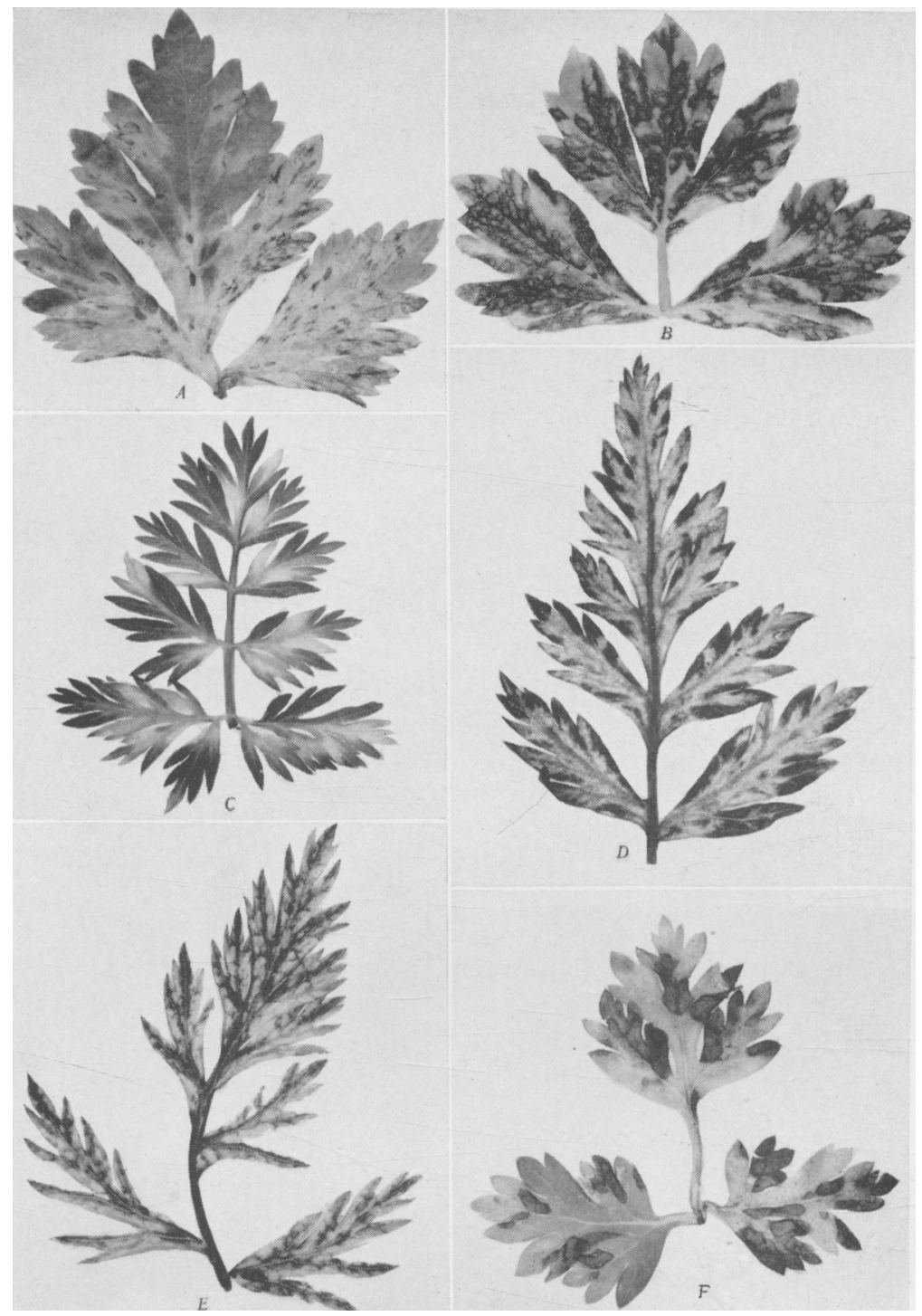

Plate 5.-Western celery mosaic: $A$, brown necrotic spots on the upper surface of celery leaflets from a plant naturally infected (Gardena, July 1, 1935); $B$, brown necrotic areas covering most of the celery leaflets from a plant experimentally infected by mechanical inoculation; $C$, carrot (Daucus Carota var. sativa) leaflets from Danvers Half Long variety infected by the rusty-banded aphid (A phis ferruginea-striata), showing chlorotic areas; $D, E$, carrot leaflets showing mottling from a plant naturally infected (Milpitas, June 10, 1936); F, curled chervil (Anthriscus Cerefolium) leaflets from a plant infected by the rusty-banded aphid, showing chlorotic areas and brown necrotic spotting. 


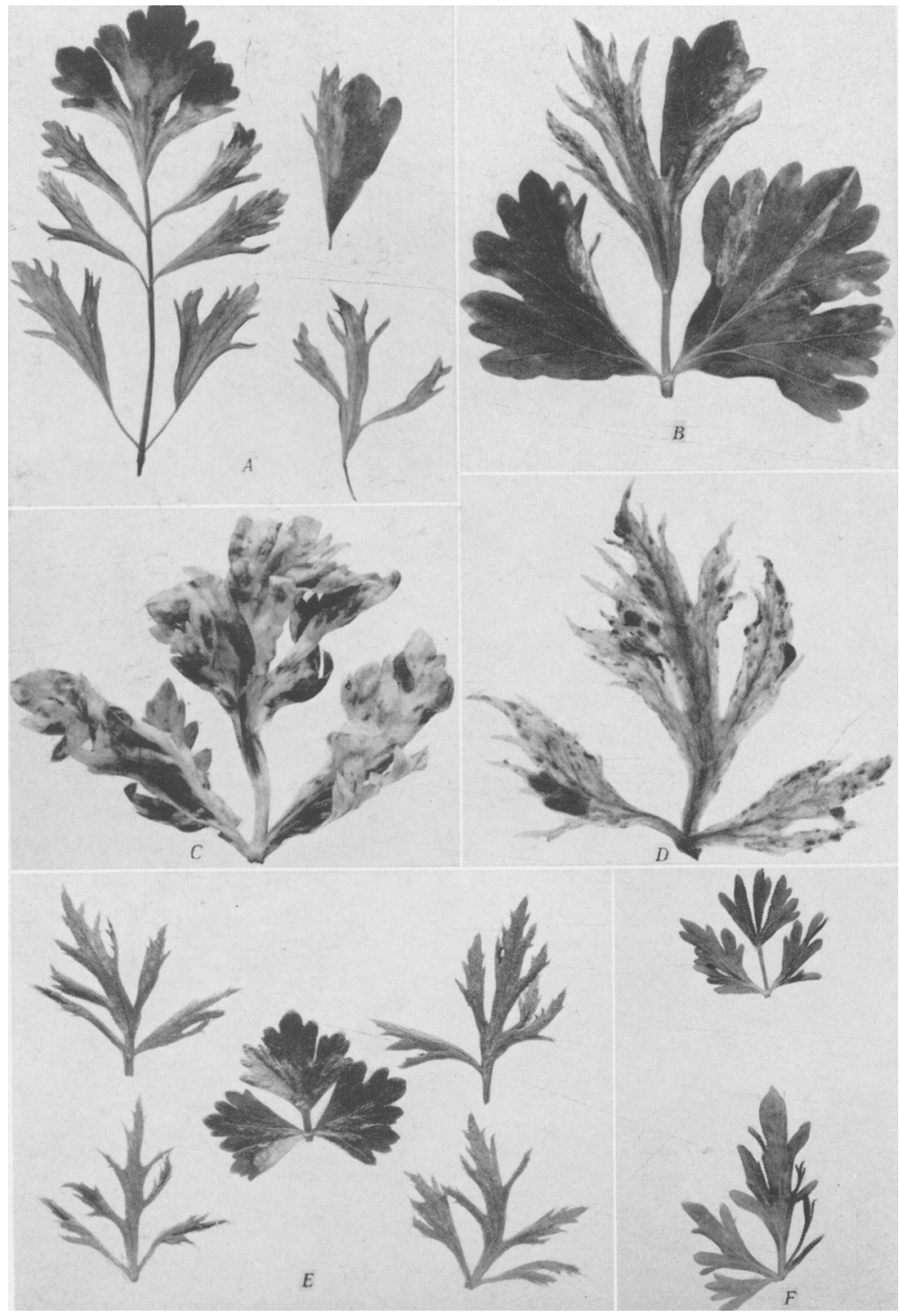

Plate 6.-A to $C$, Western celery mosaic: $A$, celery leaf with all leaflets narrow with the exception of the apical leaflet, from a plant infected by the rusty-banded aphid (Aphis ferruginea-striata) ; $B$, portion of one leaflet narrow from a celery plant experimentally infected ; $C$, malformed, twisted, thickened celery leaflets showing mottling, from a plant naturally infected (Gardena, July 1,1935 ). $D$, Celery leaflets showing blisterlike pustules resembling cucumber mosaic on celery (Milpitas, April 10, 1935). $E$, Center, celery leaflets from a healthy plant; grouped around it are four linear leaflets resembling cucumber mosaic on celery, but cucumber mosaic was not transmitted to healthy celery and cucumber plants by juice inoculations (Milpitas, April 10, 1935).F, Narrow leaflets from a healthy plant. 


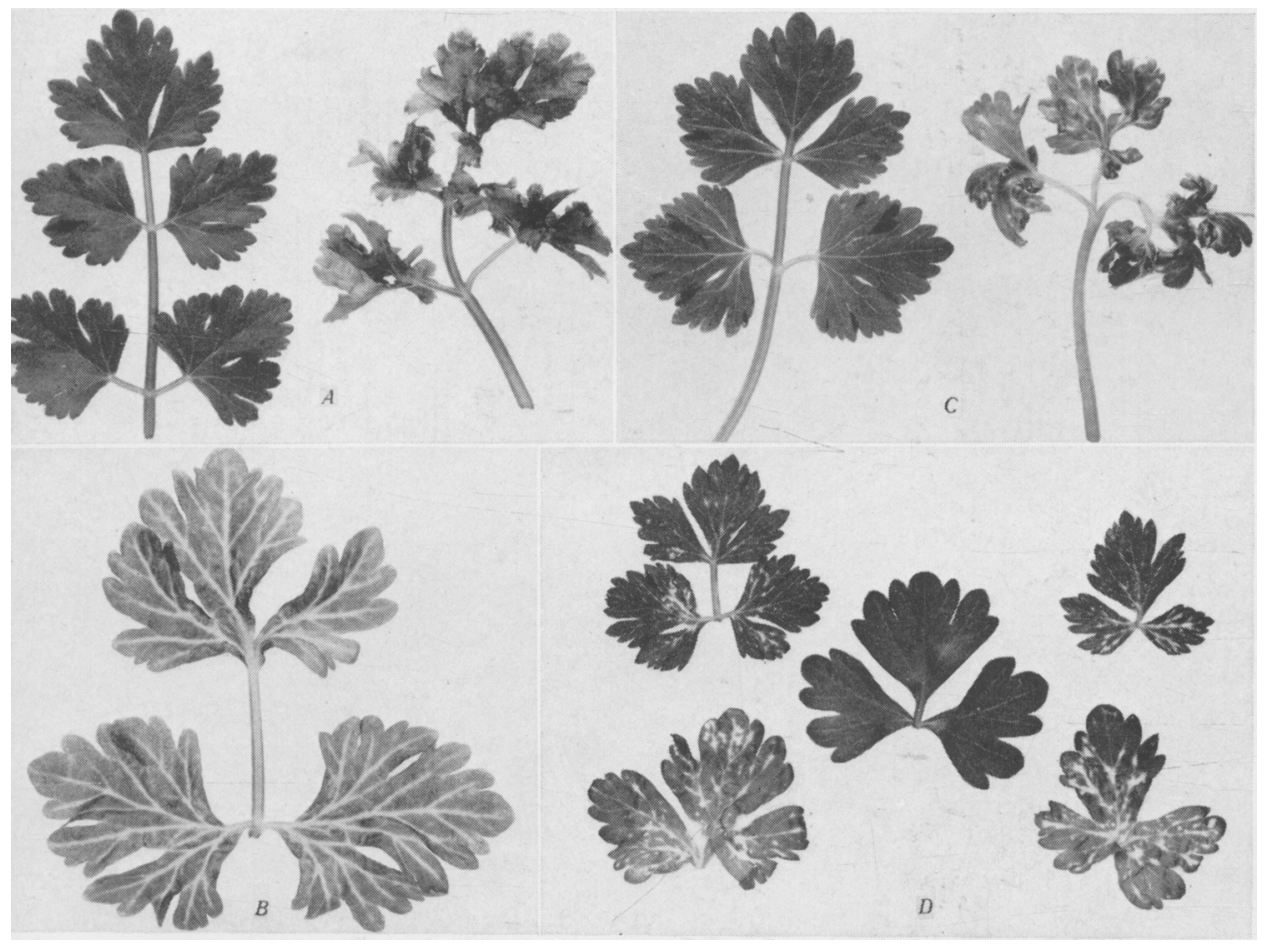

Plate 7.-A, Left, leaf from healthy celery plant; right, curled celery leaflets probably caused by feeding punctures of noninfective cotton or melon aphids (A phis gossypii). B, Celery leaf showing cleared veins probably caused by saliva of noninfective yellow willow aphids (Cavariella capreae). $C$, Left, leaf from healthy celery plant; right, curled celery leaflets probably caused by feeding punctures of noninfective foxglove aphid (Myzus convolvuli). $D$, Center, leaflets from healthy celery plant; grouped around it are four celery leaflets showing yellow spots or streaks along the veins, probably caused by the saliva of noninfective foxglove aphid. 


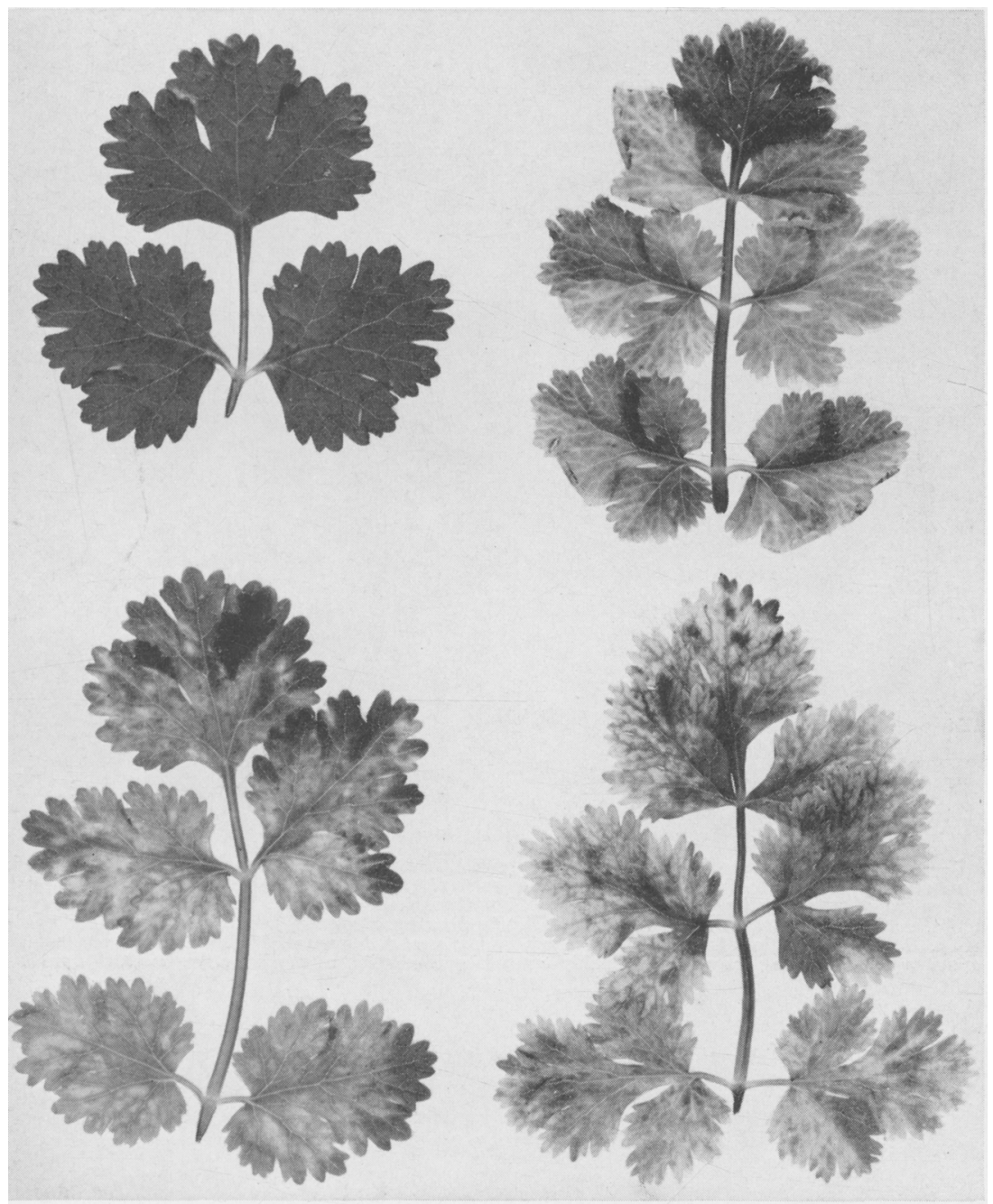

Plate 8.-Coriander (Coriandrum sativum) : upper left, leaf from check or control plant; upper right, leaf from a plant infected with western celery mosaic showing cleared veinlets; lower, leaves showing mottling. 